\title{
The radiative impact of desert dust on orographic rain in the Cévennes-Vivarais area: a case study from $\mathrm{HyMeX}$
}

\author{
C. Flamant ${ }^{1}$, J.-P. Chaboureau ${ }^{2}$, P. Chazette ${ }^{3}$, P. Di Girolamo ${ }^{4}$, T. Bourrianne ${ }^{5}$, J. Totems ${ }^{3}$, and M. Cacciani ${ }^{6}$ \\ ${ }^{1}$ Sorbonne Universités, UPMC Université Paris 06, CNRS and UVSQ, UMR 8190 LATMOS, Paris, France \\ ${ }^{2}$ Laboratoire d'Aérologie, Université of Toulouse and CNRS, Toulouse, France \\ ${ }^{3}$ LSCE, CEA-CNRS-UVSQ, Gif-sur-Yvette, France \\ ${ }^{4}$ SI-Università degli Studi della Basilicata, Potenza, Italy \\ ${ }^{5}$ CNRM, Météo-France-CNRS, Toulouse, France \\ ${ }^{6}$ Dipartimento di Fisica - Università di Roma "Sapienza", Rome, Italy \\ Correspondence to: C. Flamant (cyrille.flamant@latmos.ipsl.fr)
}

Received: 20 July 2015 - Published in Atmos. Chem. Phys. Discuss.: 21 August 2015

Revised: 19 October 2015 - Accepted: 23 October 2015 - Published: 4 November 2015

\begin{abstract}
The study is focused on Intensive Observation Period (IOP) 14 of the Hydrological Cycle in the Mediterranean Experiment first Special Observing Period (HyMeX SOP 1) that took place from 17 to 19 October 2012 and was dedicated to the study of orographic rain in the CévennesVivarais (CV) target area. During this IOP a dense dust plume originating from northern Africa (the Maghreb and Sahara) was observed to be transported over the Balearic Islands towards the south of France. The plume was characterized by an aerosol optical depth between 0.2 and 0.8 at $550 \mathrm{~nm}$, highly variable in time and space over the western Mediterranean Basin. The impact of this dust plume, the biggest event observed during the 2-month-long HyMeX SOP 1 , on the precipitation over the $\mathrm{CV}$ area has been analyzed using high-resolution simulations from the convection permitting mesoscale model Meso-NH (mesoscale non-hydrostatic model) validated against measurements obtained from numerous instruments deployed specifically during SOP 1 (ground-based/airborne water vapor and aerosol lidars, airborne microphysics probes) as well as space-borne aerosol products. The 4-day simulation reproduced realistically the temporal and spatial variability (including the vertical distribution) of the dust. The dust radiative impact led to an average $0.6 \mathrm{~K}$ heating at the altitude of the dust layer in the $\mathrm{CV}$ area (and up to $+3 \mathrm{~K}$ locally) and an average $100 \mathrm{~J} \mathrm{~kg}^{-1}$ increase of most unstable convective available potential energy (and up to $+900 \mathrm{~J} \mathrm{~kg}^{-1}$ locally) with respect to a simulation without prescribed dust aerosols. The rainfall amounts
\end{abstract}

and location were only marginally affected by the dust radiative effect, even after 4 days of simulation. The transient nature of this radiative effect in dynamical environments such as those found in the vicinity of heavy precipitation events in the Mediterranean is not sufficient to impact $24 \mathrm{~h}$ of accumulated rainfall in the dust simulation.

\section{Introduction}

Although terrigenous dust aerosols are mobilized in arid and semi-arid environments, they affect precipitation thousands of kilometers away from the source regions through complex semi-direct radiative effects (e.g., Lau et al., 2006; Huang et al., 2006b, 2009, 2014; Solmon et al., 2008; Chaboureau et al., 2011; Zhao et al., 2012) and indirect radiative effects (e.g., Rosenfeld et al., 2001; van den Heever et al., 2006; Huang et al., 2006a, 2014; Creamean et al., 2013).

Because of its proximity with the deserts of northern Africa, the largest source of dust on Earth, the Mediterranean Basin is regularly affected by outbreaks of dust located in the first few kilometers of the troposphere when generated along the coast of the Maghreb and up to $8 \mathrm{~km}$ altitude when dust is transported from the deep Sahara (Alpert et al., 2004). Dust outbreaks that reach western Europe occur mainly from late spring to early fall (Papayannis et al., 2008; Pey et al., 2013, and references therein) and are caused by low-pressure systems over the Atlantic and high pressures over northwestern 
Africa (e.g., Moulin et al., 1998; Barkan et al., 2005; Escudero et al., 2005; Querol et al., 2009). The transport of dust towards the Mediterranean from the African sources is generally associated with the strong southerly winds ahead of eastward propagating Atlantic troughs (e.g., Chaboureau et al., 2011).

Because the regional distribution of dust during southerly outbreaks over the Mediterranean Basin is highly variable in time and space, the effect of dust upon the atmospheric circulation and precipitation is similarly uncertain and needs to be investigated. The direct radiative effect of dust can impact the water cycle in two ways: through heating during the daytime at the altitude of the dust layer and cooling near the surface, below the dust layer. These processes yield opposite effects: the former leads to a destabilization of the atmosphere (favorable to enhancing convection and rainfall) and the latter leads to a stabilization. In the daytime, dust aerosols typically also reduce the net radiation impinging upon the surface which results in a reduction of evaporation and in turn of precipitation (Miller et al., 2004). In the nighttime, dustrelated forcing is much reduced with cooling being observed as the result of the longwave forcing in the dust layer, while warming is observed below the dust layer (e.g., Lemaître et al., 2010). Hence, destabilization of the atmosphere can also occur at night due to the presence of dust.

Despite the potentially significant influence of dust on the water cycle and precipitating systems in the Mediterranean, their radiative impact on quantitative precipitation forecasts in this area has received little attention so far. Chaboureau et al. (2011) investigated the radiative impact of dust on 5day precipitation forecasts over France during the Convective and Orographically induced Precipitation Study (COPS; Wulfmeyer et al., 2008) and showed that skill in rain forecasts could be increased in the 5-day range when using a dust prognostic scheme during dust episodes reaching Europe.

The objective of this study is to investigate - using high-resolution simulations from the convection permitting mesoscale model Meso-NH (mesoscale non-hydrostatic model) - the radiative impact of a large dust outbreak on a series of precipitating convective systems that occurred over the southern Massif Central in the fall of 2012, during the first Special Observing Period of the Hydrological Cycle in the Mediterranean Experiment (HyMeX SOP 1; Ducrocq et al., 2014). The HyMeX SOP 1 was dedicated to improve understanding and prediction of heavy precipitation events (HPEs).

The study is focused on Intensive Observation Period (IOP) 14 of the HyMeX SOP 1 which took place from 17 to 19 October 2012 and was dedicated to studying orographic rain in the Cévennes-Vivarais (CV) target area. During this IOP a dense mineral dust plume originating from northern Africa (the Maghreb and Sahara) was observed to be transported towards the southern French coastline and over the Balearic Islands and to lead to AODs (aerosol optical depths) between 0.2 and 0.8 at $550 \mathrm{~nm}$ over the western Mediterranean Basin and to be highly variable in time and space.

This case study was selected owing to the fact that the dust outbreak observed during IOP 14 was the biggest event observed in the course of the HyMeX SOP 1. It was also chosen because only orographic rain was forecasted to occur on the southern slopes of the Massif Central, i.e., precipitation forced by orography and not embedded in large-scale clusters such as those initiated along a cold front. Finally, the wealth of data on the vertical distribution of dust (from ground-based and airborne aerosol lidars and airborne microphysics probes) offers the great advantage of fully validating the Meso-NH simulations, in order to obtain a simulated dust radiative impact as realistic as possible.

The outline of the paper is the following. Section 2 presents the SOP 1 data sets as well as the space-borne products available during IOP 14 that are used in this study. Section 3 describes the Meso-NH model as well as the twin simulations performed (one with prognostic dust and one without dust radiative effect). Section 4 details the synoptic conditions over the western Mediterranean and the associated precipitation on the $\mathrm{CV}$ area, while the time evolution of the dust outbreak over the Mediterranean during IOP 14 is presented in Sect. 5. Section 6 discusses the radiative impact of dust on atmospheric temperature, atmospheric stability and brightness temperature (BT) at $10.8 \mu \mathrm{m}$. Section 7 gives the conclusion.

\section{Data sets}

\subsection{Ground-based aerosol and water vapor lidars}

In the framework of the HyMeX SOP 1, the atmospheric aerosol load and moisture content was monitored over the Mediterranean using two ground-based Raman lidar systems operated in Menorca (Balearic Islands) and Candillargues (near Montpellier).

The Water vapor and Aerosol Lidar (WALI; Chazette et al., 2014) was deployed in Ciutadella (Menorca, Fig. 1) from 17 September to 28 October 2012, collecting more than $1000 \mathrm{~h}$ of measurements, distributed over 42 measurement days and 10 IOPs. The lidar operates in nadir pointing mode with an emitted wavelength of $355 \mathrm{~nm}$ to fulfill eye-safe conditions. The wide field of view of $\sim 2.3 \mathrm{mrad}$ ensures a full overlap beyond $300 \mathrm{~m}$. The system operates at $20 \mathrm{~Hz}$ and monitors the total backscattering coefficient at $355 \mathrm{~nm}$ from the atmosphere, including contributions from molecules, aerosols and clouds with a vertical resolution of $30 \mathrm{~m}$. It also monitors the cross-polarized (with respect to laser emission) backscattering coefficient and the Raman scattering from water vapor and nitrogen molecules. In the following we shall analyze particle extinction coefficients at $355 \mathrm{~nm}$, water vapor mixing ratios and volume depolarization ratio profiles obtained continuously from WALI from 00:00 UTC on 17 October to 00:00 UTC on 20 October. The 


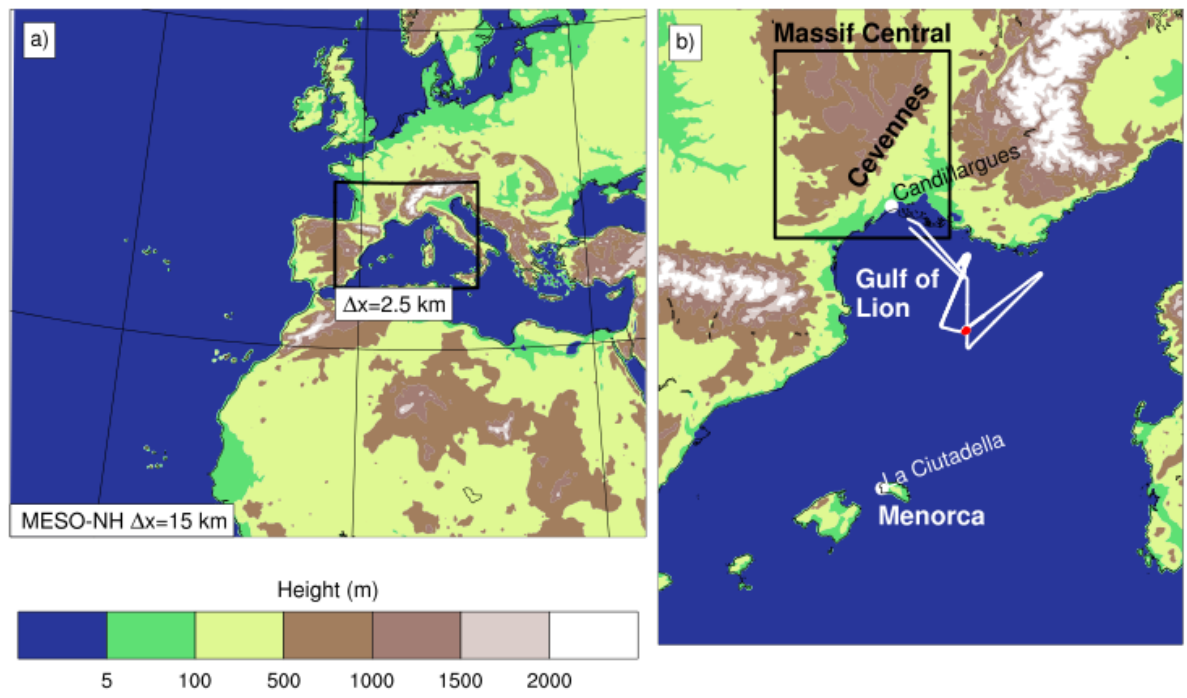

Figure 1. (a) Domains of nested Meso-NH simulations with overlaid orography. The grid size of the large domain is $15 \mathrm{~km}$ while the grid size of the nested domain is $2.5 \mathrm{~km}$. (b) Nested domain with indications of the main orographic features as well as location of instruments used in this study. The thick white line is the ATR 42 flight track on 18 October 2012 while the red dot represents the location of the aircraft sounding during which remote sensing and in situ data used in this paper were acquired. The black box defines the Cévennes-Vivarais target area $\left(2-5^{\circ} \mathrm{E}, 43.2-45.5^{\circ} \mathrm{N}\right)$, as defined for the HyMeX SOP 1 .

details of the extinction coefficient retrievals are given in Chazette et al. (2014). The maximum range of water vapor mixing ratio profiles derived from the zenith-pointing lidar is $\sim 6-7$ and $1 \mathrm{~km}$ during nighttime and daytime, respectively. It depends on the atmospheric transmission, mainly limited by the presence of aerosols or/and clouds, as well as on the level of background radiation associated with solar irradiance.

The University of Basilicata Raman Lidar system (BASIL) was deployed in Candillargues (Southern France, Fig. 1) from 25 August to 5 November 2012, collecting more than $600 \mathrm{~h}$ of measurements, distributed over 51 measurement days and 19 IOPs. The major feature of BASIL is represented by its capability to perform high-resolution and accurate measurements of atmospheric temperature and water vapor, both in daytime and nighttime (Di Girolamo et al., $2004,2009,2015)$, based on the application of the pure rotational and roto-vibrational Raman lidar technique, respectively. Besides temperature and water vapor, BASIL also provides measurements of the molecular, aerosol and cloud backscatter coefficients at 355, 532 and $1064 \mathrm{~nm}$, of particle extinction coefficients at 355 and $532 \mathrm{~nm}$, and of particle depolarization at 355 and $532 \mathrm{~nm}$. In the following, we shall analyze profiles of extinction coefficients obtained at $355 \mathrm{~nm}$ and water vapor mixing ratios.

\subsection{Airborne measurements}

During the IOP 14 of HyMeX SOP 1, airborne in situ measurements of meteorology, particles, gas, and clouds were made onboard the SAFIRE (Service des Avions Français In- strumentés pour la Recherche en Environnement) ATR 42 over the Mediterranean. The ATR 42 was also equipped with the water vapor differential absorption lidar (DIAL) LEANDRE 2 (Lidar Embarqué Aerosols Nuages Dynamique Rayonnement Environnement), operating in both nadir and zenith pointing mode.

\subsubsection{Aerosol microphysics measurements}

The size of the coarse particle is measured with a GRIMM optical particle counter (OPC, model Sky 1.129) operated inside the cabin at $6 \mathrm{~s}$ time resolution and measuring the optical size distributions between 0.25 and $32 \mu \mathrm{m}$ on 31 size classes in nominal diameter. The instrument integrates light scattering between 30 and $150^{\circ}$ at $655 \mathrm{~nm}$. The flow inside the instrument is modified by GRIMM to be constant whatever the pressure. The total number concentration of particles between $10 \mathrm{~nm}$ and $3 \mu \mathrm{m}$ in diameter was measured using a butanol-based condensation nucleus counter (CPC, TSI model 3772). The CPC sample flow is controlled by a critical orifice so flow is constant whatever the sample pressure. Both instruments are installed behind the isokinetic and isoaxial aerosol sample inlet which has a $4.3 \mu \mathrm{m}$ diameter cutoff size. Particle-phase species were sampled through a forwardfacing inlet installed in place of a side window of the aircraft. The inlet is composed of an outer sleeve for channeling air and a tube radius of curvature high enough to limit losses during transport of particles (Crumeyrolle et al., 2008). 


\subsubsection{Water vapor DIAL LEANDRE 2}

The design of the LEANDRE 2 DIAL system and the standard DIAL signal processing are given in Bruneau et al. (2001) and are only briefly presented here. The system includes a tuneable laser whose emission is positioned precisely upon an absorption line selected from two rotationvibration bands in the near-infrared spectrum $(727-770 \mathrm{~nm})$. For operations during HyMeX, an absorption band around $730 \mathrm{~nm}$ was selected. As discussed in Bruneau et al. (2001), LEANDRE 2 characteristics permit water vapor mixing ratio measurements to be made with a precision ranging from less than $0.1 \mathrm{~g} \mathrm{~kg}^{-1}$ in the mid-troposphere to less than $0.4 \mathrm{~g} \mathrm{~kg}^{-1}$ near the surface for an along-beam resolution of $150 \mathrm{~m}$ and accumulation of 100 individual profiles (corresponding to an along-track resolution of nearly $1 \mathrm{~km}$ ). Systematic errors associated with LEANDRE 2 water vapor mixing ratio retrievals are described in Bruneau et al. (2001). The vertical distribution of the aerosols in the lower troposphere was also documented using LEANDRE-2-derived reflectivity at $730 \mathrm{~nm}$, which is mostly sensitive to aerosols with radii ranging from 0.1 to $5 \mu \mathrm{m}$. The lidar reflectivity profiles were normalized to the value of the molecular backscattering coefficient (at $730 \mathrm{~nm}$ ) at an altitude of $3.5 \mathrm{~km}$ above mean sea level (km a.m.s.l.), i.e., above the observed dust plumes. The resulting lidar-derived attenuated backscattering coefficient profiles are used in this paper to analyze the two-dimensional distribution of aerosol layers at high resolution $(15 \mathrm{~m}$ in the vertical and $1 \mathrm{~km}$ in the horizontal) as in Flamant et al. (2007, 2009a, b).

\subsubsection{ATR 42 operations during IOP 14}

During IOP 14, the ATR 42 performed a flight (flight \#51, Fig. 1) above the Gulf of Lion (see Fig. 1), between 15:35 and 19:11 UTC on 18 October. Measurements were made at various altitudes in a $2^{\circ} \times 2^{\circ}$ domain (comprised between $41.5-43.5^{\circ} \mathrm{N}$ and $4-6^{\circ} \mathrm{E}$ ). During that flight sequence, the ATR 42 performed a complete sounding between 17:16 and 17:27 UTC from 3.6 to $0.3 \mathrm{kma}$ a.m.s.l. OPC and CPC measurements derived from that aircraft profile will be discussed later in the paper. During the sounding, the LEANDRE 2 DIAL operated in nadir pointing mode between 17:16 and 17:23 UTC. The LEANDRE 2 backscattering coefficient profile and water vapor mixing ratio profile averaged during this time period will be compared to the Meso-NH counterparts in the following.

\subsection{Regional networks}

The $24 \mathrm{~h}$ of accumulated precipitation derived from rain gauge networks from France and Spain, processed homogeneously for the entire SOP 1 period, is utilized to pinpoint the location and assess the rainfall efficiency of orographic rain occurring during the IOP 14 in the $\mathrm{CV}$ area.
Aerosol optical measurements derived from several photometers of the AERONET network (available from http: //aeronet.gsfc.nasa.gov/) have also been used for model validation purposes. In particular, we have used the data from the station in La Ciutadella in Menorca (see location in Fig. 1).

\subsection{Space-borne observations}

The regional distribution of dust aerosols (mobilization and transport) is described using the Moderate Resolution Imaging Spectroradiometer (MODIS) Aqua AOD fields at $550 \mathrm{~nm}$ available from the Giovanni web portal (http://disc.sci.gsfc. nasa.gov/giovanni). The MODIS AOD products used are a level 3 , gridded $\left(1^{\circ} \times 1^{\circ}\right)$, daily product, representative of the aerosol load around 13:30 UTC.

The calibrated thermal infrared BT at $10.8 \mu \mathrm{m}$ provided by Spinning Enhanced Visible and Infrared Imager (SEVIRI) on board Meteosat Second Generation has also been used to identify deep convective clouds and analyze their life cycle with a 15 min temporal resolution. A threshold of $230 \mathrm{~K}$ $\left(\sim-43^{\circ} \mathrm{C}\right)$ on BT is used to assess the presence of deep convection over the area of interest, as in Fu et al. (1990), based on visual inspection of satellite imagery. Using a different threshold, such as $250 \mathrm{~K}$ (Aoshima et al., 2008), does not change the conclusions drawn in this study.

\section{Meso-NH simulations}

During the HyMeX SOP $1,48 \mathrm{~h}$ dust forecasts done with the non-hydrostatic mesoscale model Meso-NH (Lafore et al., 1998) were provided each day using European Centre for Medium-Range Weather Forecasts (ECMWF) operational analyses and forecasts as initial and boundary conditions. The model was run with $15 \mathrm{~km}$ horizontal grid spacing over the domain with $400 \times 480$ grid points shown in Fig. 1 . In the case of heavy precipitation over the HyMeX SOP 1 area, the model was run with an additional inner grid of $648 \times 480$ grid points with a grid spacing of $2.5 \mathrm{~km}$ (Fig. 1) using the two-way interactive grid-nesting method (Stein et al., 2000). The vertical grid of the two models had 62 levels stretching from $60 \mathrm{~m}$ close to the surface to $600 \mathrm{~m}$ in the upper troposphere. Subgrid-scale processes were represented using parameterizations for surface exchanges (Masson et al., 2013), turbulence (Cuxart et al., 2000), shallow convection (Pergaud et al., 2009), mixed-phase microphysics (Pinty and Jabouille, 1998), subgrid clouds (Chaboureau and Bechtold, 2005) and radiation (Mlawer et al., 1997). The parameterization of Bechtold et al. (2001) for deep convection was activated for the outer grid only while the inner model was run as a convection-permitting model.

The dust prognostic scheme described in Grini et al. (2006) used the Dust Entrainment and Deposition (DEAD) model (Zender et al., 2003) for the calculation of dust fluxes from wind friction speeds. Once generated into the atmosphere, dust is then transported by the log-normal 
aerosol scheme of the ORganic and Inorganic Log-normal Aerosols Model (ORILAM; Tulet et al., 2005) in three modes with median radii of $0.32,1.73$ and $4.33 \mu \mathrm{m}$ and standard deviations of 1.7, 1.6 and 1.5, respectively. Dust loss occurred through sedimentation, surface deposition and scavenging. The radiative properties of dust were obtained, in the shortwave spectrum, from the photometers deployed during the African Monsoon Multidisciplinary Analyses (AMMA) programme while, in the longwave, the standard formulation of absorption and re-emission for aerosols from the ECMWF model was used (see Tulet et al., 2008, for more details). The first dust forecast started at 00:00 UTC on 29 August 2012 from aerosol-free conditions. Then, dust data at the end of a given $24 \mathrm{~h}$ forecast are passed as initial conditions at the start of the next $24 \mathrm{~h}$ forecast.

Two simulations used in this study were run for 4 days. The DUST simulation is the forecast initiated at 00:00 UTC on 17 October during the HyMeX SOP 1 and integrated for 2 more days. To quantify the radiative effects of dust, the NODUST simulation was also initiated at 00:00 UTC on 17 October but with all the radiative effects of dust switched off. The assessment of cloud fields was done using the so-called model-to-satellite approach (see Chaboureau et al. (2008) and references within). In this approach, brightness temperatures were computed from the model outputs using the radiative transfer code RTTOV (Radiative Transfer for Tiros Operational Vertical Sounder) version 8.7 (Saunders et al., 2005) and compared to satellite observations. Previous studies (Clark and Chaboureau, 2010; Chaboureau et al., 2012; Rysman et al., 2015, among others) have shown the overall skill of Meso-NH to correctly predict cloud and rain fields over the Mediterranean. The dust effect is not taken into account in RTTOV version 8.7. It is marginal in the BTs (a few kelvins for the window channels, e.g., Chaboureau et al. (2007).

To assess the quality of the Meso-NH simulations, categorical scores have been widely used to quantify the matching between observed and forecasted precipitation or high clouds amounts at model grid points (e.g., Söhne et al., 2008). Here we used the Heidke skill score (HSS), which measures the fraction of correct forecasts after eliminating those that would be correct due to chance. The HSS typically lies between 0 and 1 , the values for random and perfect forecasts, respectively. The HSS is applied to the $24 \mathrm{~h}$ rainfall amounts from the rain gauge measurements and the Meso$\mathrm{NH}$ simulations to assess the HSS as a function of a rain rate threshold.

\section{Overview of IOP 14: synoptic situation and precipitation in the $\mathrm{CV}$ area}

On 17 October a large trough began to deepen west of the Iberian Peninsula. As a result, the low-level flow turned to the south over the Mediterranean Sea, bringing moist air with orographic precipitation on the southern slope of the Massif
Central. The upper level flow over the CV area was southwesterly. Precipitation began on the southern slope of the Massif Central. The observed $24 \mathrm{~h}$ rainfall was of the order of 30-60 mm (Fig. 2a) in the form of an elongated band oriented more or less along the upper level flow. Rainfall resulted from the formation of a large cluster of stationary convective systems in the lee of the Pyrenees which progressively extended northeastward over the Massif Central as observed with SEVIRI (Fig. 2b) at the time when BT was smallest over the CV area.

On 18 October, the trough deepened to the southwest of Portugal and the upper level flow over the CV area was almost southerly while the low-level flow turned to a more southeasterly direction. Mainly stratiform rain fell over CV with some short intervals of moderate rains from the Pyrenees to the southern fringes of the Massif Central. The observed $24 \mathrm{~h}$ rainfall was similar to the previous day, with maxima in excess of $75 \mathrm{~mm}$ over the Pyrenees and the Corbières (Fig. 2c). Orographic rain in this region was the result of low-level southeasterly flow impinging on the topography at the coast. The strong southeasterly flow (in excess of $15 \mathrm{~m} \mathrm{~s}^{-1}$ ) was caused by low-level convergence over the Gulf of Lion associated with the merging of three easterly flows: an easterly flow from the Tyrrhenian defected north of Corsica along the coastline, a southeasterly flow accelerated in the strait between Corsica and Sardinia and a southeasterly flow deflected south of Sardinia (not shown). An extended cluster of deep convective systems was observed with SEVIRI over the Massif Central, which was oriented southwest-northeast, as on the previous day (Fig. 2d).

On 19 October, a cutoff was isolated on the southern part of the elongated trough near Portugal. The active cold front moved from central to eastern Spain and southwestern France, the upper-level flow being southerly over the CV area. As on 18 October, the low-level flow over the Gulf of Lion was strong and oriented almost easterly. Ahead of the front, there was an increase of precipitation on $\mathrm{CV}$ with persistent orographic rains in a more unstable air mass. Amounts of precipitation on the Pyrenees, the Corbières and southern slopes of the Massif Central ranged from 30 to $60 \mathrm{~mm}$, on average, reaching locally 60-80 mm (Fig. 2e). The largest $24 \mathrm{~h}$ rainfall amounts (in excess of $150 \mathrm{~mm}$ ) were observed in the Pyrenees, just south of the city of Lourdes. A broad region of rainfall amounts in excess of $100 \mathrm{~mm}$ was also observed north of the French-Spanish border, upstream of Lourdes. SEVIRI observations did not highlight any significant deep convective systems in the CV area, as opposed to in southwestern France (Fig. 2f).

The $24 \mathrm{~h}$ of accumulated precipitation from 00:00 UTC on 18 October to 00:00 UTC on 19 October derived from the rain gauge network in the $\mathrm{CV}$ area is shown in Fig. 3a together with its counterparts derived from DUST (Fig. 3b) and NODUST (Fig. 3c). Both simulations represent the main features of the rainfall pattern, but only small differences are seen between the $24 \mathrm{~h}$ of accumulated rain from the two sim- 

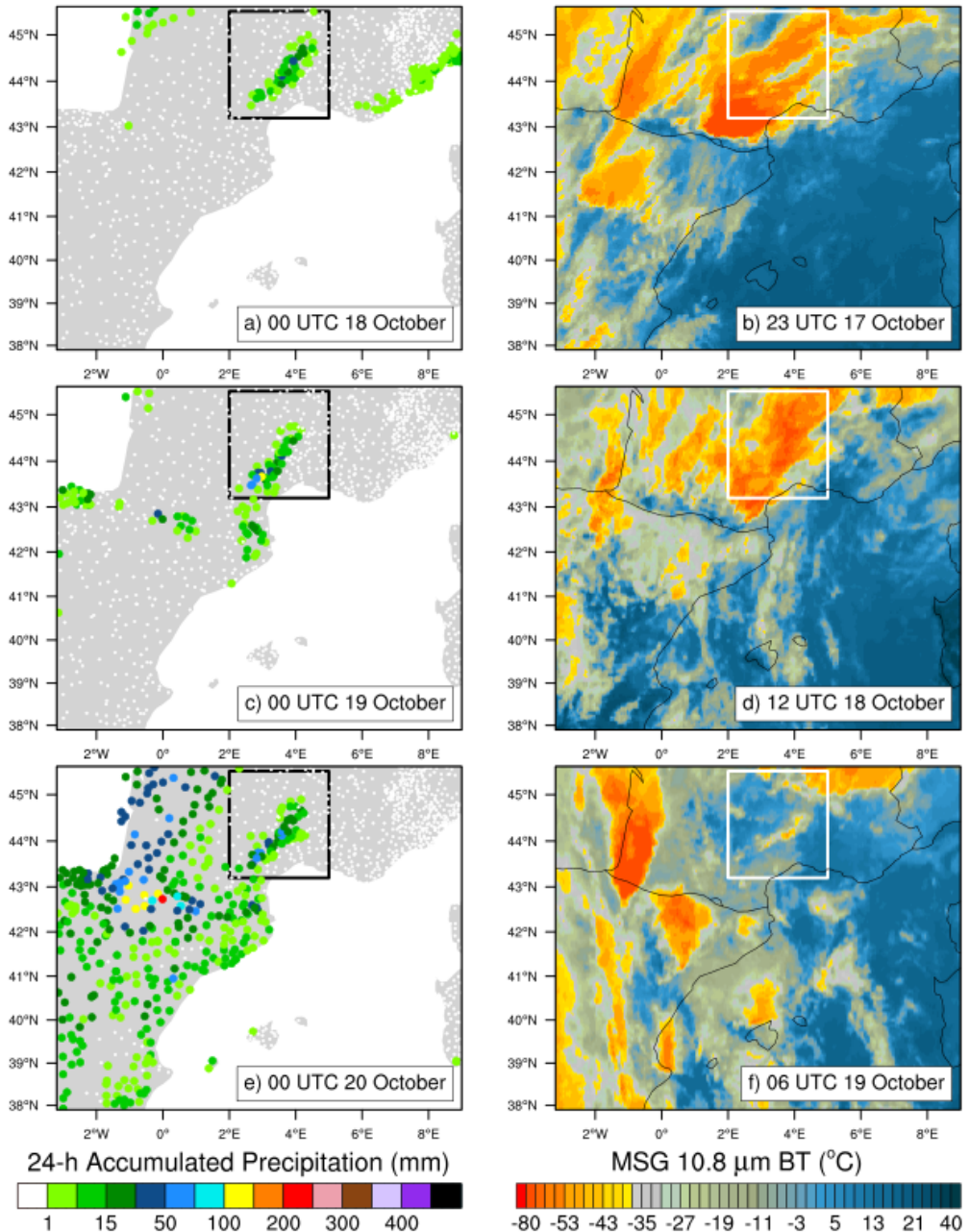

Figure 2. Left column: $24 \mathrm{~h}$ rainfall amounts (from 00:00 UTC) derived from rain gauge measurements on (a) 17 October, (c) 18 October and (e) 19 October 2012. The thick black line delineates the $\mathrm{CV}$ area $\left(2-5^{\circ} \mathrm{E}, 43.2-45.5^{\circ} \mathrm{N}\right)$. Right column: brightness temperature at $10.8 \mu \mathrm{m}$ derived from SEVIRI at (b) 23:00 UTC on 17 October, (d) 12:00 UTC on 18 October and (f) 06:00 UTC of 19 October 2012. The SEVIRI images are shown for the time when BT is smallest over the CV area. The white line delineates the CV area.

ulations. The HSS analysis shows that DUST represents a bit more realistically the intermediate rainfall intensity range (i.e., around $30 \mathrm{~mm}$ ) than NODUST (Fig. 3d). Similar findings are found for the following day, i.e., for $24 \mathrm{~h}$ of accumulated precipitation between 00:00 UTC on 19 October and 00:00 UTC on 20 October (Fig. 3e-h). Larger values are observed and simulated with respect to the previous day as seen in the observations (Fig. 3e) and in the DUST and NODUST simulations (Fig. 3f and g, respectively). The HSS values for the DUST simulation are appreciably larger than their NODUST counterpart (Fig. 3h), unlike on the previous day (Fig. 3d). On the other hand, the HSS for the rainfall intensity range between 5 and $40 \mathrm{~mm}$ is smaller than for the previous $24 \mathrm{~h}$, while the HSS for large rain rates is larger (Fig. 3h).

In order to understand whether this is related to the overall quality of the dust simulation, in the next section we discuss the origin and evolution of the intense dust event ob- served over the Mediterranean during IOP 14 and compare the DUST simulation to a suite of ground-based, airborne and space-borne observations.

\section{Dust transport over the Mediterranean during IOP 14}

Over the Mediterranean, rather low MODIS-derived AODs (less than 0.2 at $550 \mathrm{~nm}$ ) were observed on 17 October (Fig. 4a). The highest AOD values were observed north of Morocco and Algeria, east of the Gibraltar Strait. The retrievals over the area are impaired by the presence of clouds ahead of the approaching trough. In DUST simulation, valid at 12:00 UTC (Fig. 4d), the largest AOD values are restricted to northern Africa, suggesting that the northward transport of dust is slightly delayed in the simulation. 


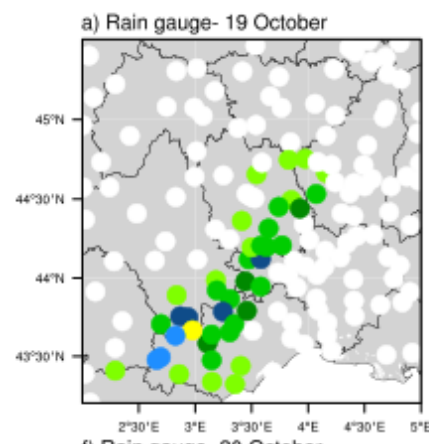

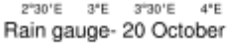
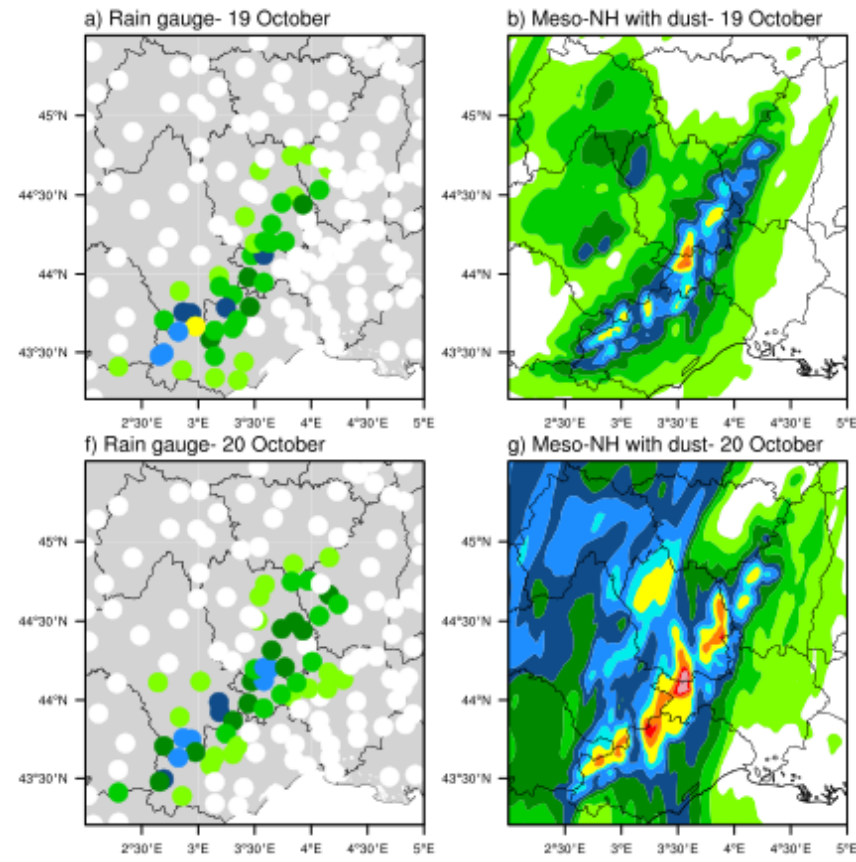

24-h Accumulated precipitation (mm)
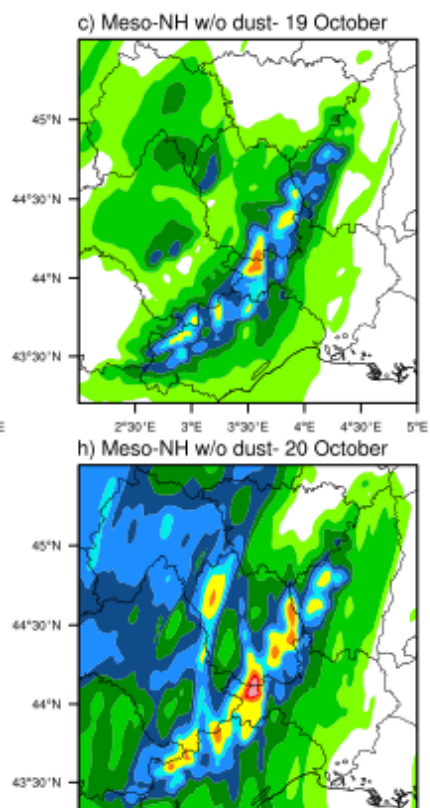

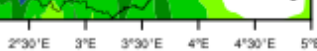

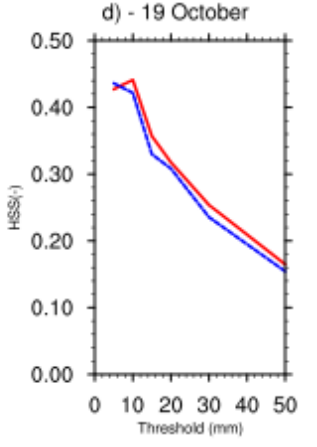

h) -20 October

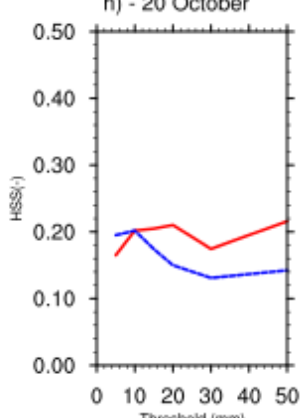

$\begin{array}{llllll}0 & 10 & 20 & 30 & 40 & 50\end{array}$

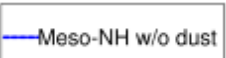

Meso-NH w/o dust
Meso-NH with dust

Figure 3. (a) $24 \mathrm{~h}$ of accumulated rainfall from 00:00 UTC on 18 October derived from the rain gauge network in the CV domain. (b) $24 \mathrm{~h}$ of accumulated rainfall derived from the DUST Meso-NH simulation. (c) same as (a) but for the NODUST Meso-NH simulation. (d) HSS as a function of the rainfall threshold for the DUST simulation (solid red line) and the NODUST simulation (solid blue line). (e-h) same as (a-d), respectively, but for $24 \mathrm{~h}$ of accumulated rainfall from 00:00 UTC on 19 October 2012.

On 18 October, MODIS AODs in excess of 0.5 are observed over the Mediterranean, east of the Spanish coastline, extending as far as southern France and as far east as Corsica (Fig. 4b). In DUST simulation, valid at 12:00 UTC, the dust plume exiting from the northwestern part of Algeria is also seen to be located east of the Spanish coastline and to reach Menorca and the Gulf of Lion (where ATR operations took place) as well as the vicinity of Candillargues (Fig. 4e). The core of the plume is seen to be located south of the island of Menorca, whereas the MODIS observations suggest the dust plume to be spreading further east than in the simulation. The plume is oriented along the mean upper flow direction as shown by the orientation of the simulated flow at $3 \mathrm{~km}$ a.m.s.l.

On 19 October, the plume appears to be widespread over the western Mediterranean Basin and to have shifted northeastward with respect to the previous day (Fig. 4c). The largest AODs are located over the Gulf of Lion and between Menorca and Corsica. The simulated plume is less optically thick than on the previous day, dust being mostly limited to the western Mediterranean Basin, west of Corsica and Sardinia (Fig. 4f). The eastern edge of the main simulated plume is positioned just to the east of Menorca and the orientation of the plume is aligned with the upper-level flow at $3 \mathrm{~km}$ a.m.s.l.

The high extinction coefficient values observed below $1 \mathrm{~km}$ by WALI during most of 17 October (Fig. 5a) are related to a mix of low-level clouds and sea spray, and are not simulated with Meso-NH (Fig. 5b). This is further confirmed by the lack of depolarization observed with WALI (not shown, see Fig. 11 in Chazette et al., 2014). Very few clouds were observed in Menorca by the lidar during the period of interest. Low-level clouds were observed at the top of the marine boundary layer from 17 to 19 October, prior to the arrival of the dust event (see Fig. 11 of Chazette et al., 2014). A second layer of more intermittent clouds was also observed above the dust plume (i.e., above $3.5 \mathrm{~km}$ a.m.s.l. on 18 October and above $3 \mathrm{~km}$ a.m.s.l. on 19 October). The clouds produced rain which was responsible for the lidar data gaps on 19 October. The cloud layers are well represented in the Meso-NH DUST simulation using a cloud condensate mixing ratio of $0.005 \mathrm{~g} \mathrm{~kg}^{-1}$.

The arrival of the dust plume in Menorca is detected in the WALI extinction coefficient data around 22:00 UTC on 17 October and confirmed by the depolarization ratio data (not shown). High extinction values $\left(>0.1 \mathrm{~km}^{-1}\right)$ 
a) MODIS 17 October
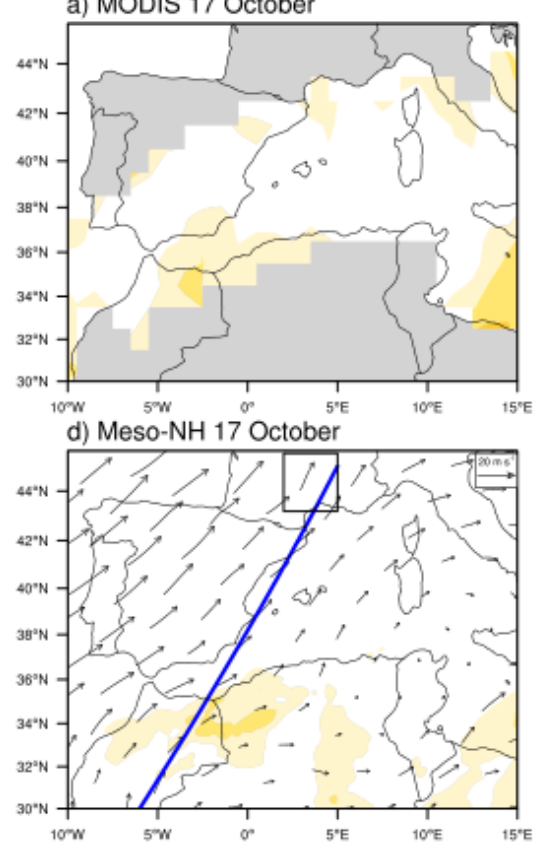

b) MODIS 18 October

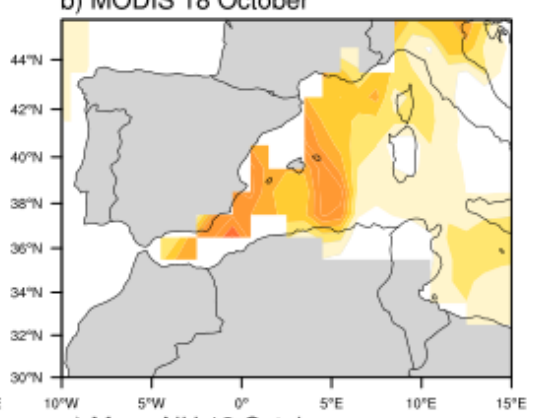

e) Meso-NH 18 October c) MODIS 19 October

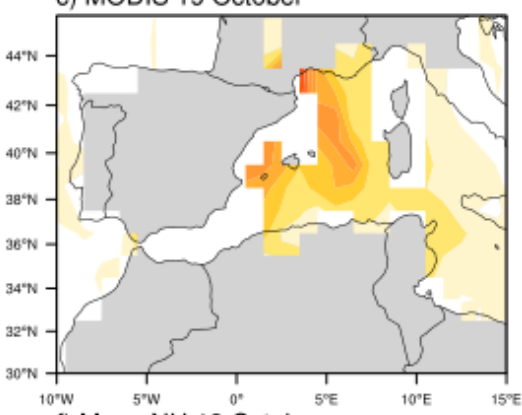

f) Meso-NH 19 October
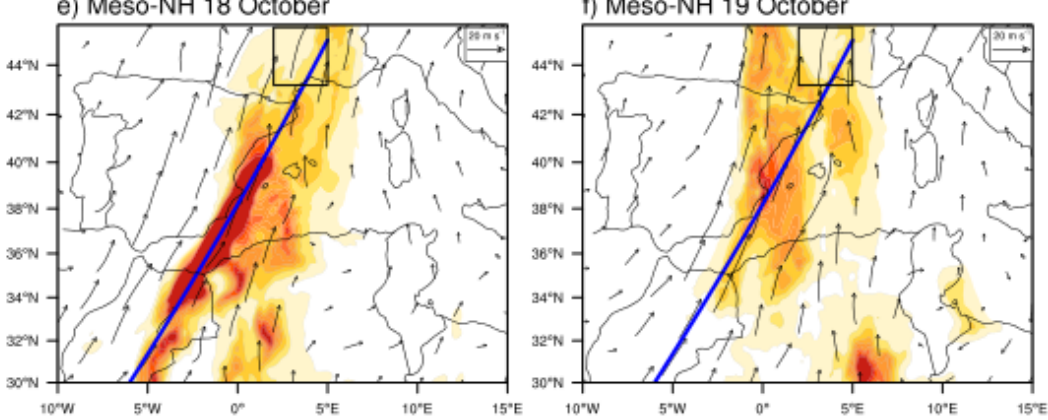

Aerosol Optical Depth (-)

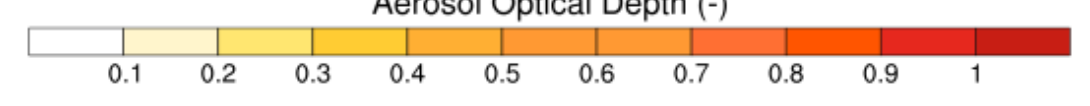

Figure 4. Top panels: MODIS Aqua-derived AOD at 13:30 UTC on (a) 17 October, (b) 18 October and (c) 19 October 2012. Meso-NH DUST simulation of AOD at 12:00 UTC on (d) 17 October, (e) 18 October and (f) 19 October 2012. Bottom panels: the simulated horizontal wind field at $3 \mathrm{~km}$ a.m.s.l. (vectors) is superimposed on panels (d-f) with the scale of the vectors given in the upper right corner of the panels. The blue solid line indicates the position of the vertical cross sections shown in Fig. 8. The black box shows the CV area.

are seen between 0.2 and $2 \mathrm{kma}$.m.s.l. until 19 October 00:00 UTC and then between 0.2 and $4.5 \mathrm{~km}$ until 19 October 12:00 UTC. Later that day, the vertical extent of the dust plume is seen to decrease with time until 00:00 UTC on 20 October. Low-level dust observed on 18 October suggests dust emission at the coast of northern Africa, while elevated dust observed on 19 October suggests transport from more remote locations such as southern Algeria.

In the simulation, the arrival of the low-level dust in Menorca is seen at approximately the same time as in the observations. The general structure of the dust plume is reproduced by the simulation, in particular the two deeper parts of the plume observed at 12:00 UTC on 18 October and 06:00 UTC on 19 October, even though being simulated $6 \mathrm{~h}$ ahead (i.e., 06:00 UTC on 18 October and 00:00 UTC on 19 October) of their observed counterparts. This is confirmed by the measurements from the sunphotometer in Menorca showing large AOD values around 12:00 UTC on 18 October which compare well with WALI observations but trail the Meso-NH AOD peak by $\sim 6 \mathrm{~h}$ (Fig. $5 \mathrm{e}$ ). Also, the end of the dust episode is simulated $\sim 6 \mathrm{~h}$ prior to the one observed with the AERONET and $\sim 3 \mathrm{~h}$ prior to the one derived from WALI. Finally, on average, the modeled AOD is biased high against the WALI observations during the period of the dust event. The water vapor mixing ratio data from WALI show a descending tongue of dry air (likely associated with the tropopause folding ahead of the approaching trough) intruding in the lower troposphere between 21:30 UTC on 17 October and 07:00 UTC on 18 October (Fig. 5c). A similar feature is seen in the simulation to start at the same time and altitude (i.e., $3 \mathrm{~km}$ a.m.s.l.) as in the observations but to descend to $2 \mathrm{~km}$ much faster than in the observations. The depth of the marine boundary layer is also simulated to be deeper than in the WALI observations during the dust event.

Figure 6a shows the BASIL-derived profiles of the extinction coefficient at $355 \mathrm{~nm}$ over Candillargues during IOP 14 . The presence of low-level clouds at the top of the PBL (planetary boundary layer) prevented extinction coefficient retrievals for most of the period of interest, except on 18 October. The arrival of dust in Candillargues is observed around 04:00 UTC on 18 October in BASIL extinction data as also confirmed by the volume depolarization ratio measurements (not shown). Typical dust extinction values are found to be on the order of $0.1 \mathrm{~km}^{-1}$ at $532 \mathrm{~nm}$, i.e., much less than the values observed in the upper part of the moist PBL prior to 04:00 UTC (in excess of $0.25 \mathrm{~km}^{-1}$ ). The larger values are caused by clouds which were more numerous in Candillargues than in Menorca, as evidenced from the cloud mask 


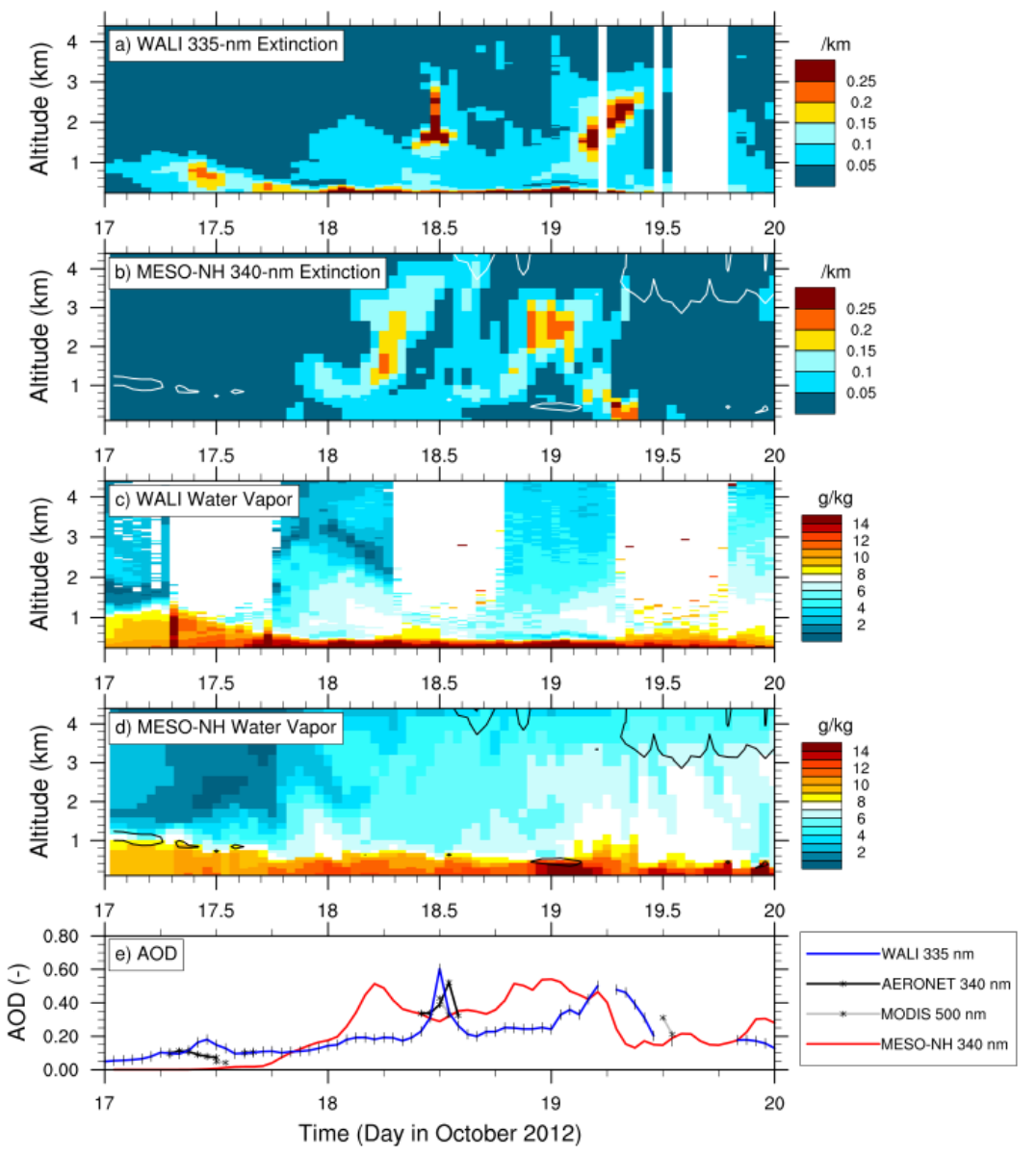

Figure 5. Time-height series of extinction coefficients derived from (a) WALI at $355 \mathrm{~nm}$ and (b) the Meso-NH DUST simulation - valid for the spectral range 0.25-0.44 $\mu \mathrm{m}$ - over Menorca between 00:00 UTC on 17 October and 00:00 UTC on 20 October 2012. Data gaps in (a) appear in white and are due to rain. (c) and (d) same as (a) and (b) but for the water vapor mixing ratio. The cloud layers in the Meso-NH DUST simulation are shown using a cloud condensate mixing ratio of $0.005 \mathrm{~g} \mathrm{~kg}^{-1}$ (white contours in $\mathbf{b}$ and black contours in d). (e) AOD evolution for the same time period as derived from WALI (blue solid line), AERONET (at $340 \mathrm{~nm}$, black solid line), MODIS (grey solid line) and the Meso-NH DUST simulation (red solid line). Error bars on the AOD retrievals are \pm 0.03 and \pm 0.02 for AERONET and WALI retrievals, respectively.

derived from the lidar data in Fig. 6a. Low-level clouds are observed at the top of the boundary layer at the beginning of the dust event on 18 October, as well as at the top of the dust plume later on. The Meso-NH simulation also shows the presence of a thick cloud condensate layer at the top of the boundary layer, which looks more contiguous than in the observations and the clouds above $3 \mathrm{~km}$ a.m.s.l., as in Menorca.

As observed in Menorca with WALI, the depth of the PBL decreases with the arrival of the dust, the large extinction values observed in the lower part of the PBL not being related to dust but rather to continental aerosols and low-level clouds. The dust layer is observed between 1 and $2.5 \mathrm{~km}$ a.m.s.l. until 11:00 UTC. The vertical extent of the dust plume is seen to increase significantly afterwards until the early hours of 19 October and to reach $4 \mathrm{~km}$ a.m.s.l. The largest extinction coefficient values are observed near the top of the plume. Very dry air is seen to be associated with the dust plume (wa- ter vapor mixing ratio less than $5 \mathrm{~g} \mathrm{~kg}^{-1}$ ), while the PBL in Candillargues is characterized by water vapor mixing ratios on the order of $10 \mathrm{~g} \mathrm{~kg}^{-1}$ or more (Fig. 6e). Overall, Meso$\mathrm{NH}$ overestimates the depth of the PBL and the water vapor mixing ratio values in the PBL during most of 18 October (Fig. 6e). Nevertheless, the structure of the dust plume is well depicted by the Meso-NH DUST simulation (Fig. 6d).

The dust layer is also observed in the LEANDRE 2 data acquired above the Gulf of Lion between 17:16 and 17:23 UTC on 18 October (Fig. 7d, f). The presence of dust is observed above $2 \mathrm{~km}$ a.m.s.l. (as in Candillargues further north). Strong backscattering coefficients associated with the dust are observed in a $700 \mathrm{~m}$ deep layer generally around $42^{\circ} \mathrm{N}, 5.2^{\circ} \mathrm{E}$ (Fig. 7f). The comparison is carried out with a Meso-NH profile extracted from DUST at a later time (i.e., 21:00 UTC) and approximately $100 \mathrm{~km}$ north of the position of the aircraft profile (see the locations "dst" and "obs" in 


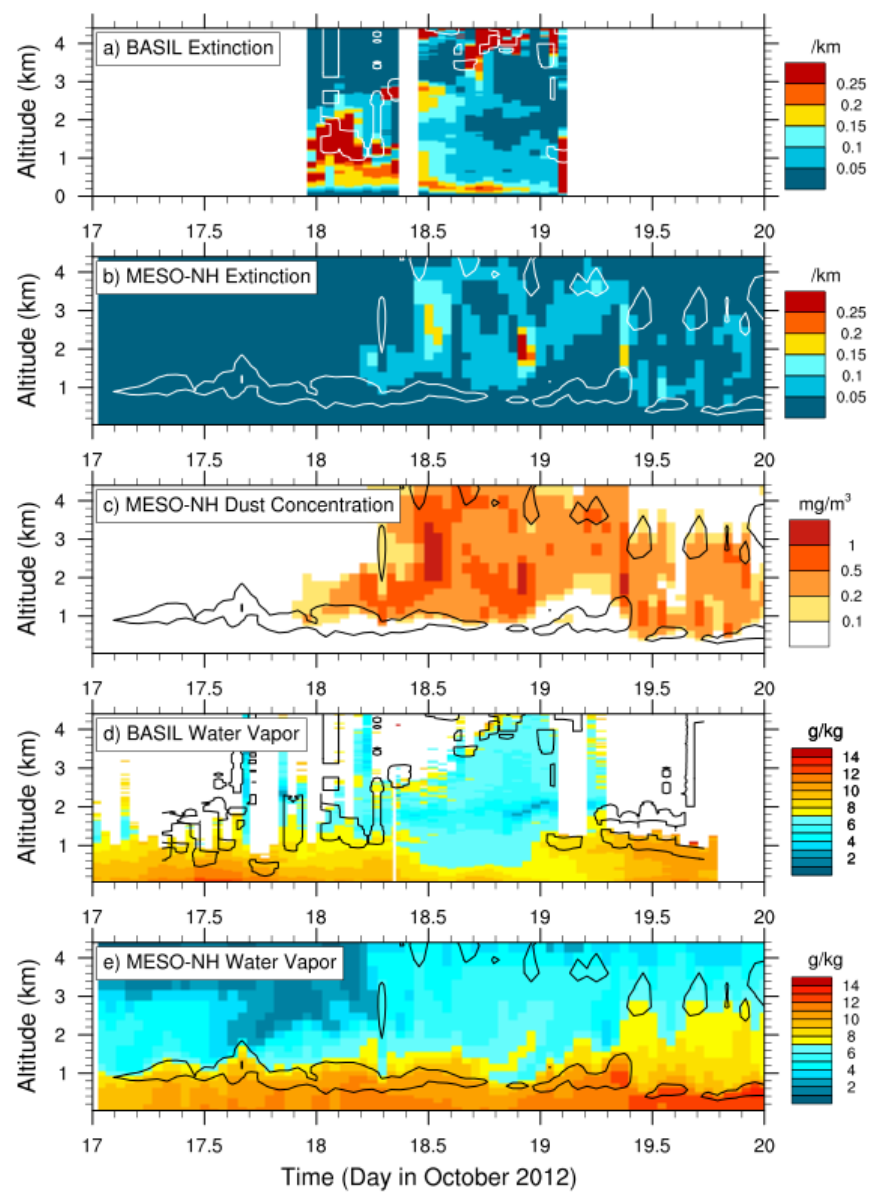

Figure 6. Time-height series of extinction coefficients derived from (a) BASIL at $355 \mathrm{~nm}$ and (b) the Meso-NH DUST simulation - valid for the spectral range 0.25-0.44 $\mu \mathrm{m}$ - over Candillargues between 00:00 UTC on 17 October and 00:00 UTC on 20 October 2012. Missing BASIL data appear in white. (c) Same as (b) but for dust aerosol concentration derived from the Meso-NH DUST simulation. (d) and (e) same as (a) and (b) but for the water vapor mixing ratio. The cloud layers in the Meso-NH DUST simulation are shown using a cloud condensate mixing ratio of $0.005 \mathrm{~g} \mathrm{~kg}^{-1}$ (white contour in $\mathbf{b}$ and black contour in $\mathbf{d}$ ). The cloud mask in (a) and (c) is based on the BASIL extinction coefficient, using a threshold of $0.25 \mathrm{~km}^{-1}$. Hence, the presence of clouds is shown by the white contours in (a) and the black contours in (d), respectively. The cloud layers in the Meso-NH DUST simulation are shown using a cloud condensate mixing ratio of $0.005 \mathrm{gkg}^{-1}$ (white contours in $\mathbf{b}$ and black contours in $\mathbf{d}$ and $\mathbf{e})$.

Fig. 7k). The selected profile was the best match obtained with the LEANDRE-2-observed dust plume. The best match is obtained by minimizing the difference between the lidarderived backscattering coefficient profiles, averaged over the cross sections shown in Fig. 7a, and Meso-NH profiles at grid points in the vicinity of the observations. Because we do not expect the simulation to give the best comparison at the exact location of the observations, we have compared systematically all Meso-NH profiles within a distance of $150 \mathrm{~km}$ of the observations and selected the profile exhibiting the smallest difference. High backscattering values observed with LEANDRE 2 below $0.5 \mathrm{~km}$ a.m.s.l. (Fig. $7 \mathrm{~d}$ ) are related to the presence of sea-salt aerosols in the marine boundary layer and hence are not reproduced in the dust simulation (Fig. 7e). The simulation also shows the presence of a second dust layer above $3.5 \mathrm{~km}$ a.m.s.l. (Fig. 7f), which is observed only at the beginning of the aircraft profile to be slightly lower than in the simulation (Fig. 7d). This elevated layer was observed with LEANDRE 2 in other parts of the flight and with BASIL in Candillargues (not shown).

The marine boundary layer in the Meso-NH simulation is characterized by an average water vapor mixing ratio value of $11 \mathrm{~g} \mathrm{~kg}^{-1}$ (Fig. 7b, c), i.e., the model is moist biased by about $1 \mathrm{~g} \mathrm{~kg}^{-1}$ when compared to the LEANDRE 2 observations (Fig. 7a). The comparison is carried out with a Meso$\mathrm{NH}$ profile extracted from the dust simulation at a later time (i.e., 21:00 UTC) and approximately $70 \mathrm{~km}$ north of the position aircraft profile (see the location "dry" and "obs", respectively in Fig. 71). The selected profile was the best match obtained with the LEANDRE-2-observed moisture field. The dust layer is associated with water vapor mixing ratio values of $5 \mathrm{~g} \mathrm{~kg}^{-1}$ and is located above a drier layer $\left(3 \mathrm{~g} \mathrm{~kg}^{-1}\right)$, this 

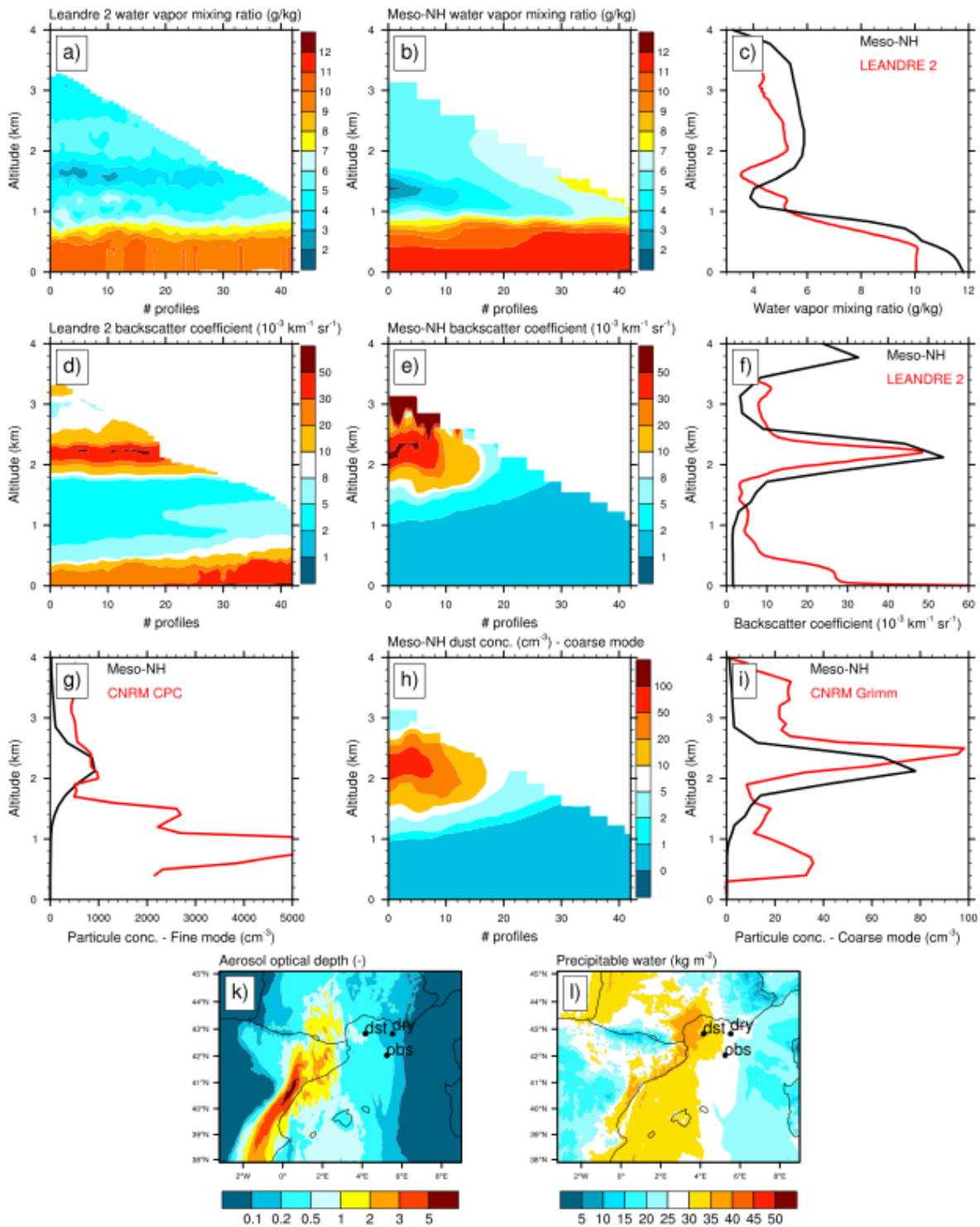

Figure 7. (a) LEANDRE-2-derived water vapor mixing ratio between 17:16 and 17:23 UTC along the aircraft profile marked as "obs" in (l). (b) Meso-NH water vapor mixing ratio at 21:00 UTC for the same horizontal extent as (a) but at the location marked as "dry" in (l). (c) Average vertical profiles of water vapor mixing ratio from LEANDRE 2 (red solid line) and Meso-NH DUST (black solid line) derived from (a) and (b), respectively. (k) LEANDRE-2-derived attenuated backscattering coefficient between 17:16 and 17:23 UTC along the aircraft profile marked as "obs" in (j). (d) Meso-NH DUST backscattering coefficient at 21:00 UTC at the location marked as "dst" in (k). (f) Average vertical profiles of backscattering coefficients from LEANDRE 2 (red solid line) and Meso-NH DUST (black solid line) derived from (d) and (e), respectively. (g) Vertical profiles of fine-mode particle concentration from CPC measurements (red solid line) acquired during the aircraft sounding ("obs" in k) between 17:16 and 17:27 UTC and from Meso-NH DUST (black solid line) at 21:00 UTC. (h) Meso-NH DUST coarse-mode particle concentration at 21:00 UTC at the location marked as "dst" in (k). (i) same as (g) but for coarsemode particle concentration. (k) AOD field derived from the Meso-NH DUST simulation with the location of the observational and modeled soundings overlaid. (l) Same as (k) but for the integrated water vapor content.

type of layering having already been observed during COPS (Chaboureau et al., 2011; Behrendt et al., 2011). This drier layer is represented in the simulation (Fig. 7b), the dust layer being embedded in a moister environment than in the observations.
The aircraft sounding performed between 17:16 and 17:27 UTC around $42^{\circ} \mathrm{N}, 5.2^{\circ} \mathrm{E}$ allowed sampling in situ the thermodynamics in the lower troposphere as well as the characteristics of the aerosols observed by lidar below the aircraft. Strong easterly winds (in excess of $20 \mathrm{~m} \mathrm{~s}^{-1}$ ) are observed between 0.3 and $1 \mathrm{kma.m} . \mathrm{s} .1$. and are likely gen- 

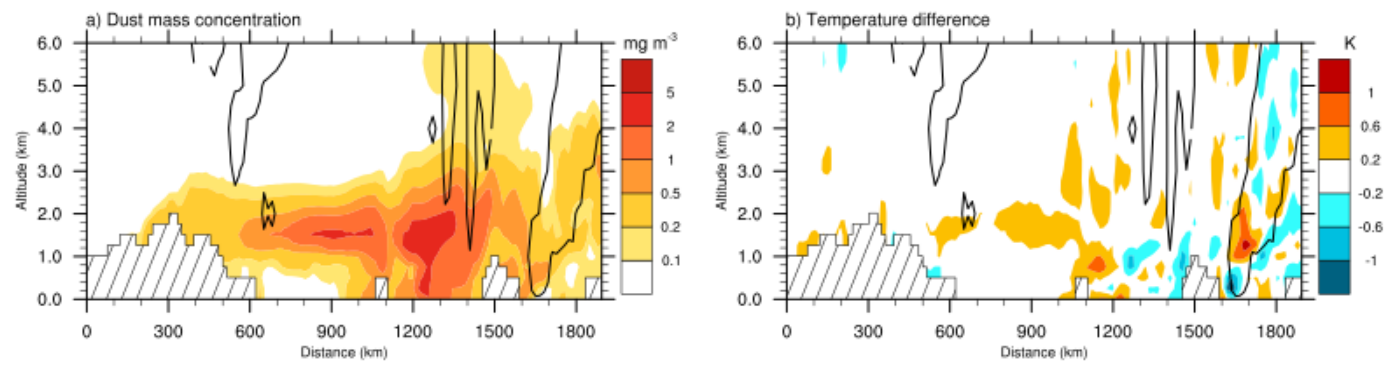

Figure 8. (a) Vertical cross section of dust concentration (color scale) and cloud condensate mixing ratio of $0.01 \mathrm{~g} \mathrm{~kg}^{-1}$ (contours) along the transect shown in Fig. 4 from $30^{\circ} \mathrm{N}, 6^{\circ} \mathrm{W}$ to $45^{\circ} \mathrm{N}, 5^{\circ} \mathrm{E}$ at 12:00 UTC on 19 October 2012. The orography is also shown (hatched areas). (b) same as (a) but for the difference in temperature between DUST and NODUST (color scale).

erating the production of sea spray in the boundary layer observed with LEANDRE 2. Good agreement is also found between the in situ measurements of the water vapor mixing ratio and the LEANDRE 2 retrievals between 0.3 and $3.2 \mathrm{~km}$ a.m.s.1.

High concentrations of coarse particles measured with the GRIMM OPC are observed above $2 \mathrm{kma.m.s.l.} \mathrm{(in} \mathrm{excess}$ of 20 particles $\mathrm{m}^{-3}$; Fig. 7i), the elevated maximum corresponding to the enhanced attenuated backscattering coefficient derived from the LEANDRE 2 measurements (Fig. 7f). The second maximum of coarse particles observed in the marine boundary layer is related to the presence of sea-salt aerosols, as also observed with LEANDRE 2. A maximum of fine-mode particles (in excess of 1000 particles $\mathrm{cm}^{-3}$ ) is observed with the CPC above the boundary layer and below the dust layer (Fig. 7g), related to nucleation events in the free troposphere as described in Rose et al. (2015). These fine-mode aerosols are neither simulated nor observed with LEANDRE 2, which is sensitive to larger aerosols.

\section{Radiative impact of dust on convective systems and associated precipitation}

The radiative impact of desert dust on convective systems and associated precipitation is analyzed using the Meso-NH simulations. We shall first illustrate and discuss this impact based on temperature and most unstable convective available potential energy (MuCAPE) fields valid on 19 October (the last day of IOP 14) when it is at its maximum, due to an important accumulation of dust in the simulation. The discussion is then extended to the entire IOP based on the analysis of time series of several key variables extracted in the $\mathrm{CV}$ area.

The vertical structure of the dust plume along the transect shown in Fig. 4 is shown in Fig. 8a (shaded area). It highlights the transport of dust over the Mediterranean between 1 and $2 \mathrm{~km}$ as well as the accumulation (local maximum) south of the Pyrenees and the vertical redistribution imposed by the clouds over the southern slopes of the Pyrenees and over the $\mathrm{CV}$ area further north (cloud boundaries are marked as black contours corresponding to a cloud condensate mixing ratio of $\left.0.01 \mathrm{~g} \mathrm{~kg}^{-1}\right)$. A cooling effect $(\sim-0.4 \mathrm{~K})$ is evidenced along the southern slopes of the Pyrenees and over the CV area below the dust layer when looking at the difference in the temperature fields between DUST and NODUST. This cooling may be associated with the radiative impact of dust but could also be due to cloud shading effects and/or radiatively cooled downdrafts below the clouds. On the other hand, warming $(\sim+0.4 \mathrm{~K})$ is seen to be generally co-localized with dust, especially in the upper part of the dust plume as, for instance, over Spain and over the CV area within the cloud. Hence, dust-related warming is likely contributing to the destabilization of air masses in the southern part of the CV area.

Fig. 9 shows the 3-hourly evolution of the difference in temperature between the DUST and NODUST simulations from 09:00 UTC to 18:00 UTC on 19 October 2012. The temperature differences at 500 ma.m.s.l. (Fig. 9a-d) and 2500 ma.m.s.l. (Fig. 9e-h) are seen to be highly variable in time and space, thereby suggesting the radiative impact of dust to be mostly a transient effect, even though part of the simulated variability may be due to differences in the location of clouds between the two simulations and the related effects (cooling due to shading, rain, cool downdrafts and warming due to latent heat release). Figure 9i-1 show the difference in cloud content between the DUST and NODUST simulations between 09:00 and 18:00 UTC. One can note that the differences, positive or negative, are always found within the dust plume (see the dust plume contour highlighted by an AOD of 0.1 in Fig. 9). This strongly suggests that the dust is the cause of these differences. The initial disruptive effect due to dust radiative impact likely combines with other induced effects such as the production and dissipation of clouds, the radiative impact of clouds and cloud dynamics, to produce non-linearly growing differences in cloud content and temperature as seen in Fig. 9a-h. In all cases, positive temperature differences in excess of $1.5 \mathrm{~K}$ can be seen in the $\mathrm{CV}$ area at 500 and $2000 \mathrm{~m}$ a.m.s.l. but only over very limited regions. This is not entirely surprising given the fact that large concentrations of aerosols and stationary conditions are generally needed in order to generate significant heating and destabilization of the atmosphere, and because these con- 

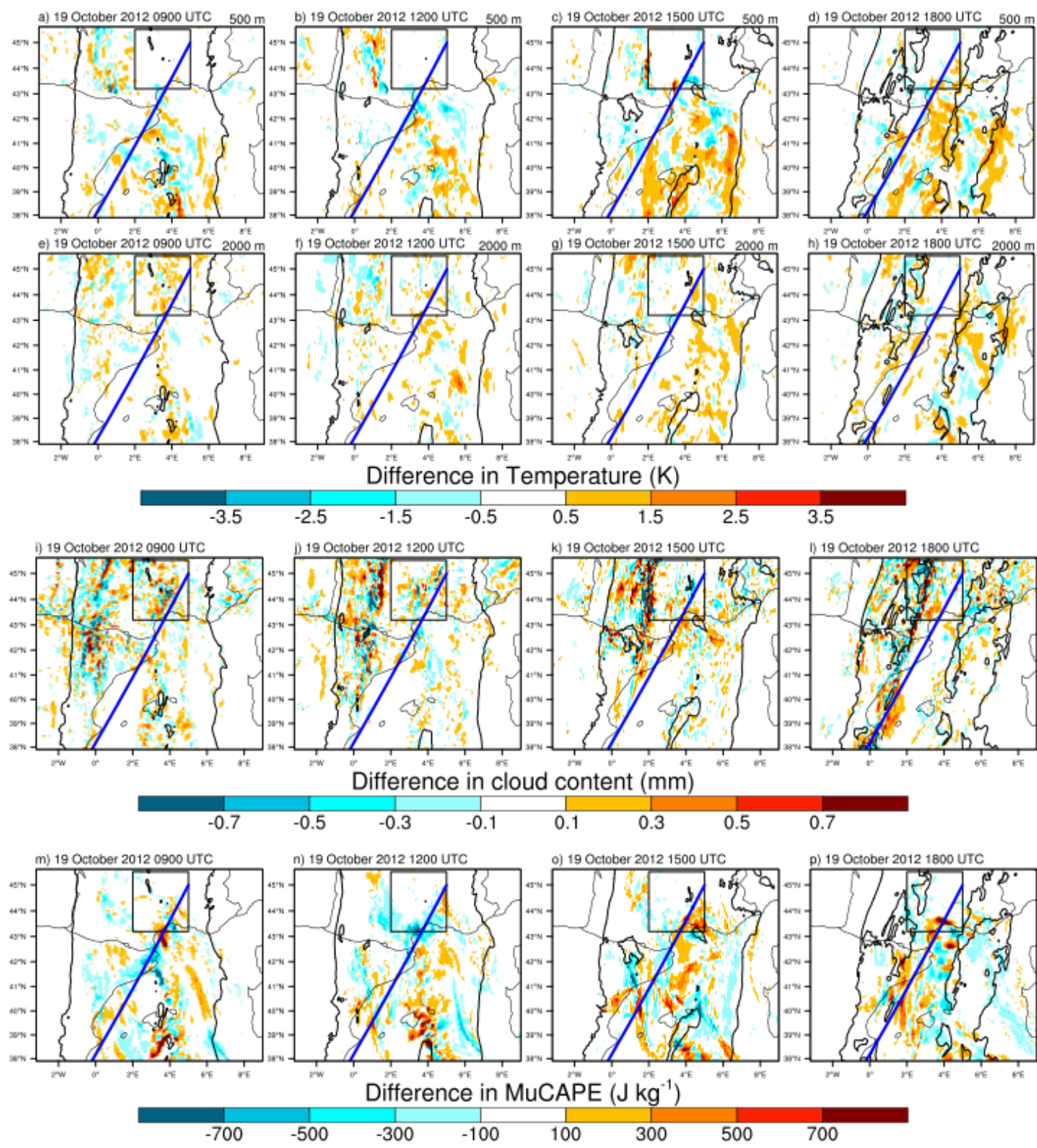

Figure 9. Top panels: 3-hourly field of difference in temperature at $500 \mathrm{~m}$ between the DUST and NODUST simulations between 09:00 and 15:00 UTC on 19 October (a-d). Middle panels: same as top panels but for differences in temperature at $2500 \mathrm{~m}$ (e-h). Middle panels: 3-hourly field of difference in cloud content (i-l). Bottom panels: as middle panels but for the difference in MuCAPE (m-p). The black line shows the AOD of 0.1 . The blue solid line indicates the position of the vertical cross sections shown in Fig. 8. The black box shows the CV area.

ditions are very difficult to find in dynamical environments such as those found in the vicinity of HPEs in the Mediterranean.

The 3-hourly evolution of the difference in MuCAPE between DUST and NODUST from 09:00 to 18:00 UTC on 19 October is also shown in Fig. 9m-p. Large differences in MuCAPE between the two simulations are seen at all times over the $\mathrm{CV}$ area, suggesting that the radiative impact of dust can generate substantial destabilization of the air masses; however, the transient nature of this effect is likely not sufficient to impact rainfall in DUST as shown in Fig. 3. Nevertheless, it is worth noting that the largest positive values of MuCAPE differences are always found within the dust plume (see the dust plume contour represented by an AOD of 0.1 in Fig. 9). Given that the only difference between the two simulations is that radiative effects of dust are switched off in NODUST, this is an indication that dust is in large part responsible for the modification in the MuCAPE distribution. 


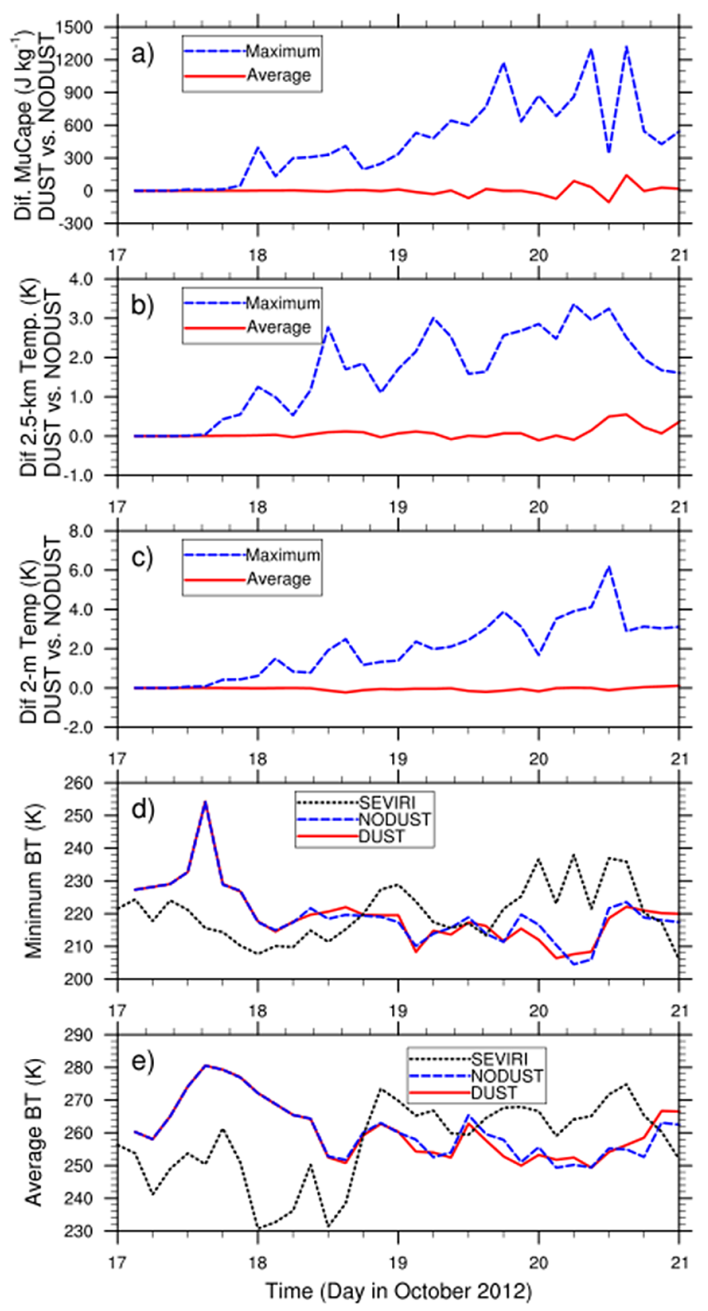

Figure 10. (a) 3-hourly evolution of the maximum MuCAPE difference (dashed blue line) in the CV domain and the MuCAPE difference averaged over the CV domain (solid red line) between DUST and NODUST from 00:00 UTC on 17 October to 00:00 UTC on 21 October 2012. (b) same as (a) but for the temperature difference at $2.5 \mathrm{~km}$ a.m.s.1. (c) same as (b) but at 500 a m.s.l. (d) 3-hourly evolution of the minimum $10.8 \mu \mathrm{m}$ BT in NODUST (dashed blue line) and in DUST (solid red line) in the CV domain. The dotted line is the minimum BT in the CV area observed with SEVIRI. (e) same as (d) but for the $10.8 \mu \mathrm{m}$ BT averaged over the CV domain.

Furthermore, MuCAPE can be viewed as an integrator of all stabilization/destabilization effects in the atmosphere (as opposed to temperature) and is easier to interpret than fields of DUST/NODUST temperature differences whose interpretation can differ between daytime and nighttime and in the presence of key features of the water cycle, i.e., clouds and water vapor.

We now look at these processes in a more systematic way over the CV area during IOP 14. Because the air masses at different levels are moving quickly in and out of the CV area, looking at the maximum values of MuCAPE or minimum values of BT is the most effective way of tracking a convective cell within the domain of interest.

The radiative impact of dust on atmospheric stability in the CV domain can be seen in Fig. 10a. The maximum MuCAPE difference between DUST and NODUST shows an increasing trend from $0 \mathrm{~J} \mathrm{~kg}^{-1}$ on 17 October to $900 \mathrm{~J} \mathrm{~kg}^{-1}$ on average on 20 October 2012, with several maxima in excess of $1200 \mathrm{~J} \mathrm{~kg}^{-1}$. This indeed suggests that dust can play a role in destabilizing the atmosphere at a small scale. This is corroborated by the trend in the maximum difference of temperature at $2 \mathrm{~m}$ between DUST and NODUST, which exhibits an increasing trend between 0 at the beginning of 17 October and $\sim 4 \mathrm{~K}$ around 12:00 UTC on 20 October 2012 (Fig. 10c). During the same period, the maximum temperature difference at $2.5 \mathrm{~km}$, i.e., the maximum height of the dust plume transported over the Mediterranean, is also simulated to increase from 0 to $3 \mathrm{~K}$, suggesting strong destabilization of the atmosphere over the CV area (Fig. 10b) even though the maximum at $2 \mathrm{~m}$ a.m.s.l. and $2.5 \mathrm{~km}$ a.m.s.l. may not necessarily be coincident in location.

When looking at these quantities averaged over the CV domain it appears that the differences in MuCAPE and temperature are much reduced, either because of a small number of grid cells impacted by strong destabilization or due to a compensating effect between grid cells with strong destabilization and strong stabilization. In all cases, the average temperature difference at $2 \mathrm{~m}$ is almost zero throughout the length of the simulation, whereas a slight positive value of the temperature difference at $2.5 \mathrm{~km}$ is simulated $(0.6 \mathrm{~K}$ after 12:00 UTC on 20 October) and small differences in MuCAPE (reaching $+100 \mathrm{~J} \mathrm{~kg}^{-1}$ at most) are simulated only on 20 October. This suggests an overall very weak radiative impact on atmospheric stability in the CV area.

When analyzing the time series of average BT from SEVIRI over the CV area (Fig. 10e), two periods can be distinguished: first a 2-day period (17 and 18 October) in which averaged BTs are lower than during the second 2-day (19 and 20 October), suggesting that the 17-18 October period was impacted by more widespread convection as shown for the afternoon of 17 October in Fig. 11. While SEVIRI shows that a deep convective cell forms to the northeast of the Pyrenees (18:00 UTC on 17 October) before moving into the CV area (00:00 UTC on 18 October), the convection remains close to the northern Pyrenees and extends towards CV in DUST and NODUST, thereby yielding higher BT values over the CV area than in the observations. The dust and dust-free simulations produce similar averaged BTs on 17 and 18 October and only slightly different averaged BTs on the following 2 days (Fig. 10e). Moreover, there are no systematic differences between the averaged BTs from the two simulations, suggesting that dust radiative impact is generally negligible over the domain. Furthermore, the averaged BTs in simulations exhibit a decreasing trend over the 4 days, suggesting a reinforcement of convection over the $\mathrm{CV}$ area, unlike what is observed with SEVIRI. This decreasing trend is also 


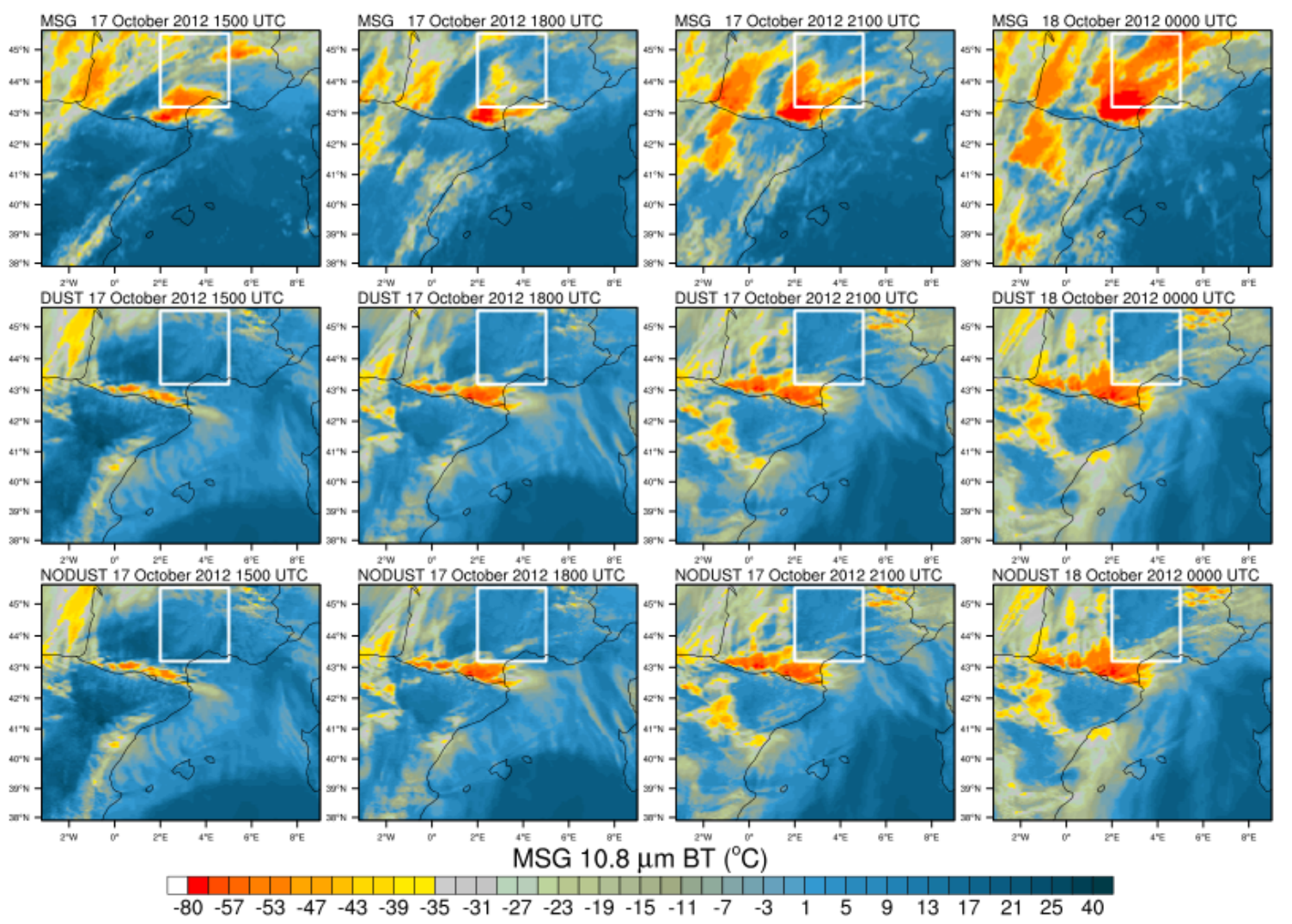

Figure 11. Top panels: 3-hourly field of BT at 10.8 $\mu$ m between 15:00 UTC on 17 October and 00:00 UTC on 18 October 2012. Middle panels: same as top panels but for BT extracted from DUST. Bottom panels: same as middle panels but for BT extracted from NODUST. The white box shows the CV area.

detectable in the temporal evolution of the minimum BTs, which was also always found below the $230 \mathrm{~K}$ threshold, except on 17 October. On the other hand, as observed for the averaged BTs, the evolution of the minimum of BTs shows a contrasting trend, i.e., larger values at the end of IOP 14 than at the beginning. This is corroborated by the SEVIRI imagery for the afternoon of 19 October (Fig. 12), which shows nearly deep-convection-free conditions over the CV area, as opposed to what is seen in the DUST and NODUST simulations in which isolated deep convection is present along the northern edge of the $\mathrm{CV}$ area.

\section{Summary, discussion and conclusions}

The direct radiative impact of a moderately intense dust plume (AOD between 0.2 and 0.8 at $550 \mathrm{~nm}$ ) from northern Africa on precipitation over the southern fringes of the Massif Central was investigated during IOP 14 of the HyMeX SOP 1. A high-resolution mesoscale simulation with prognostic dust, validated against numerous ground-based, airborne and space-borne aerosol data sets, was used to assess the dust radiative impact by comparison with a highresolution simulation that took no dust effects into account.
The simulation with prognostic dust was first shown to simulate the most intense dust plume observed during the HyMeX SOP 1 , in terms of spatiotemporal variability but also, and more importantly, in terms of vertical distribution and dust aerosol concentration. Comparison against satellitebased observations of deep convection in the CV area revealed that the model did not always produce isolated convection and mesoscale convective systems in the right place and that it underestimated (overestimated) the cloud cover associated with deeper clouds, as yielded by the simulated BT at $10.8 \mu \mathrm{m}$, during the first (last) part of IOP 14. Nevertheless, the structure of the $24 \mathrm{~h}$ of accumulated rainfall pattern was found to be consistent with that derived from observations made with an extended network of rain gages.

The radiative impact of dust on orographic rain occurring over the CV area during IOP 14 was shown to be large in some instances (up to $+3 \mathrm{~K}$ in the lower troposphere and up to $900 \mathrm{~J} \mathrm{~kg}^{-1}$ for MuCAPE), highly variable in time and space, and limited to small parts of the CV area. The radiative impact of dust at a given time was shown to be small on average over the CV area due to compensating effects: areas in which dust leads to the destabilization of the atmospheric column, thereby favoring deep convection, were gen- 


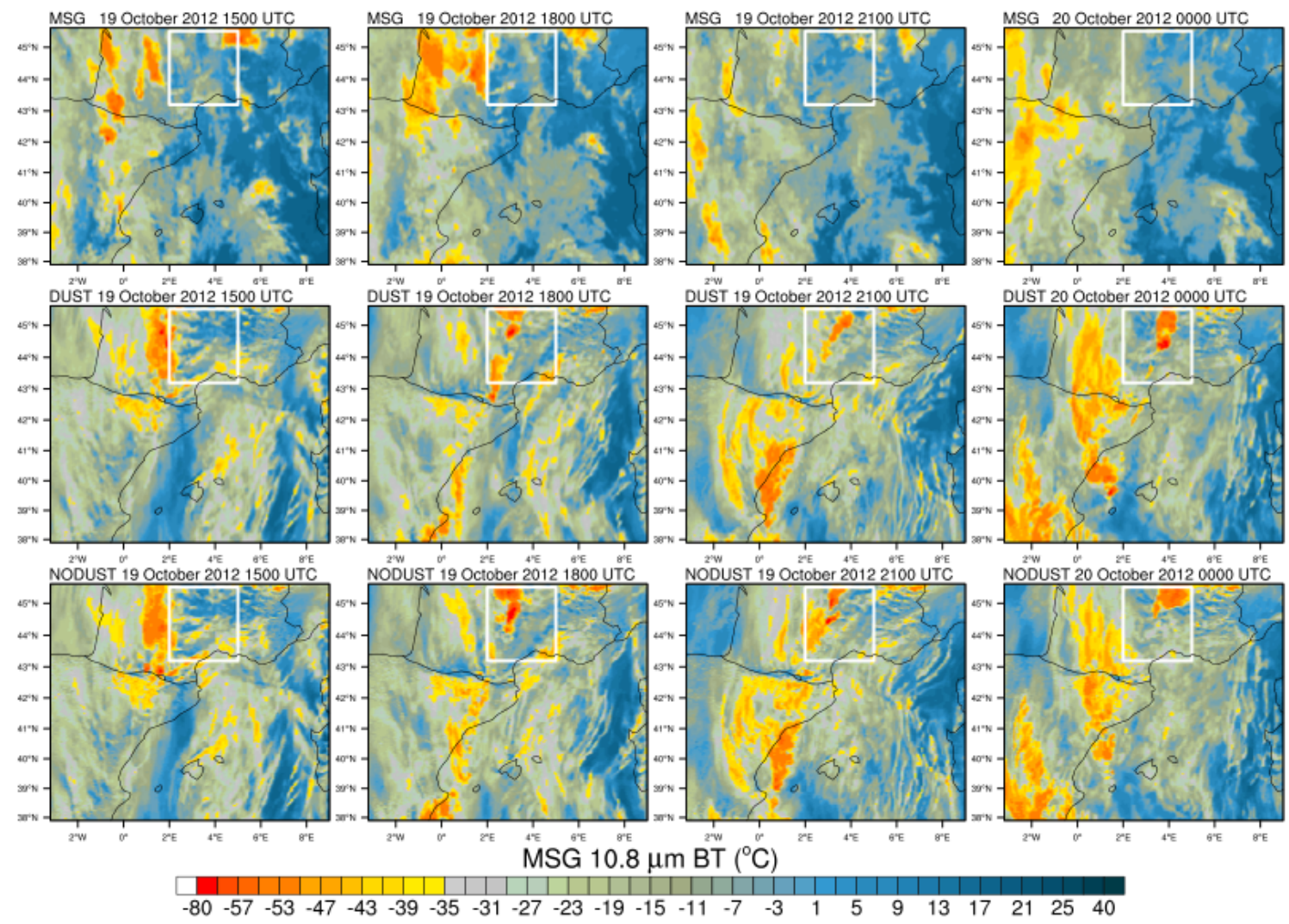

Figure 12. Same as Fig. 11 but for the afternoon of 19 October.

erally seen surrounded by even larger areas in which dust was seen to stabilize the atmosphere. Part of the simulated variability is likely due to differences in the location of clouds between the two simulations and the related effects (cooling due to shading, rain and cool downdrafts, and warming due to latent heat release). The rather small radiative impact is thought to be due to the relatively small AODs associated with the dust plume (even though these were the largest observed over the western Mediterranean during the SOP 1) but also to the transient nature of the forcing. Because orographic rain of the $\mathrm{CV}$ area during IOP 14 occurred in a very dynamic environment (as is often the case with heavy precipitation events in the Mediterranean area during the fall), the fast moving, dust-laden, lower tropospheric flow did not allow for radiative impact to build up in any part of the CV area in order to lead to sustained destabilization of the atmospheric column. Nevertheless, the largest positive values of MuCAPE differences were always found within the dust plume, an indication that the dust's direct radiative effect is partly responsible for the modification in the MuCAPE distribution.

In order to verify our hypothesis that the transient nature of the dust radiative forcing is what is limiting the impact on atmospheric stability, even under the influence of a very dense dust plume, we have designed further simulations (not presented in this work) in which the dust aerosol concentration artificially increased by a factor of 40 the emissions over northern Africa. The resulting AODs and aerosol concentrations over the Mediterranean were simulated to be twice as large as simulated and observed during IOP 14 . The radia- 
tive impact was found to be slightly larger and to affect more significantly temperature in the lower troposphere and $\mathrm{Mu}-$ CAPE, but the overall the structure of the precipitation observed and simulated during IOP 14 (Fig. 3) remained unchanged. In this dust-enhanced simulation, the transient aspect of the radiative forcing resulting from the dynamical environment prevented any significant atmospheric destabilization in the CV area.

Finally, in this study we only consider the radiative impact of dust. However, there is now evidence that mineral dust alters cloud microphysics and precipitation through so-called indirect effects (e.g., the review by Tao et al., 2012, and references therein). For instance, desert dusts have been shown to lead to the suppression of coalescence and precipitation processes (Rosenfeld et al., 2001). Min et al. (2009) found that the microphysical effects of the dust aerosols could shift the precipitation size spectrum from heavy precipitation to light precipitation in the stratiform regions of mesoscale convective systems over the Gulf of Guinea. Our analysis reveals that, when comparing observed and simulated BT fields (a proxy for deep convection), opposite trends are found. For instance, towards the end of IOP 14 , when the dust plume reaches the Mediterranean and the CV area, no deep convection is observed with SEVIRI whereas sporadic deep convection is simulated in the Meso-NH DUST run. This could be an indication that, in reality, precipitation may have been suppressed due to the dust indirect effect, which is not accounted for in the present Meso-NH simulation. Future work should be conducted to address the indirect impact of dust on orographic precipitation and heavy precipitation events using the wealth of dedicated aerosol and cloud microphysics measurements acquired in the framework of the HyMeX SOP 1 as well as the newly developed LIMA - Liquid, Ice, Multiple Aerosol - scheme (Vié et al., 2015).

Acknowledgements. This work was supported by the French Agence Nationale de la Recherche (ANR) via the IODA-MED grant ANR-11-BS56-0005, the MUSIC grant ANR-14-CE01-014, the MISTRALS/HyMeX programme, the French space agency (CNES) and the Commissariat à l'Energie Atomique (CEA). Airborne data was obtained using the ATR-42 Environment Research Aircraft operated and managed by Service des Avions Français Instrumentés pour la Recherche en Environnement (SAFIRE), which is a joint entity of CNRS, Météo-France and CNES. The SAFIRE staff is thanked for their support during SOP 1. The authors are grateful to D. Bruneau, P. Genau, C. Merlet, R. Meynadier, T. Deleporte, S. Bastin, C. Kocha, C. Lavaysse (LATMOS), as well as F. Blouzon and A. Abchiche (DT/INSU) for operating the LEANDRE 2 system aboard the ATR-42 during the HyMeX SOP 1. E. Freney (LaMP), F. Burnet and G. Momboise (CNRM) are also thanked for operating the aerosol microphysics instruments and for helpful discussions. We also would like to thank the two anonymous referees for their highly relevant comments that helped to improve the overall quality of the paper.

Edited by: J. Huang

\section{References}

Alpert, P., Kishcha, P., Shtivelman, A., Krichak, S. O., and Joseph, J. H.: Vertical distribution of Saharan dust based on 2.5 year model predictions, Atmos. Res.,70, 109-130, 2004.

Aoshima, F., Behrendt, A., Bauer, H.-S., and Wulfmeyer, V.: Statistics of convection initiation by use of Meteosat rapid scan data during the Convection and Orographically-induced Precipitation Study (COPS), Meteorol. Z., 17, 921-930, 2008.

Barkan, J., Alpert, P., Kutiel, H., and Kishcha, P.: Synoptics of dust transportation days from Africa toward Italy and central Europe, J. Geophys. Res., 110, D07208, doi:10.1029/2004JD005222, 2005.

Bechtold, P., Bazile, E., Guichard, F., Mascart, P., and Richard, E.: A mass flux convection scheme for regional and global models, Q. J. Roy. Meteor. Soc., 127, 869-886, 2001.

Behrendt, A., Pal, S., Aoshima, F., Bender, M., Blyth, A., Corsmeier, U., Cuesta, J., Dick, D., Dorninger, M., Flamant, C., Di Girolamo, P., Gorgas, T., Huang, Y., Kalthoff, K., Khodayar, S., Mannstein, H., Trümner, K., Wieser, A., and Wulfmeyer, V.: Observation of Convection Initiation Processes with a Suite of State-of-the-Art Research Instruments during COPS IOP8b, Q. J. Roy. Meteor. Soc., 137, 81-100, 2011.

Bruneau, D., Quaglia, P., Flamant, C., and Pelon, J.: The Airborne Lidar LEANDRE 2 for Water Vapor Profiling in the Troposphere. Part II: First Results, Appl. Opt., 40, 3462-3475, 2001.

Chaboureau, J.-P. and Bechtold, P.: Statistical representation of clouds in a regional model and the impact on the diurnal cycle of convection during Tropical Convection, Cirrus and Nitrogen Oxides (TROCCINOX), J. Geophys. Res., 110, D17103, doi:10.1029/2004JD005645, 2005.

Chaboureau, J.-P., Tulet, P., and Mari, C.: Diurnal cycle of dust and cirrus over West Africa as seen from Meteosat Second Generation satellite and a regional forecast model, Geophys. Res. Lett., 34, L02822, doi:10.1029/2006GL027771, 2007.

Chaboureau, J.-P., Söhne, N., Pinty, J.-P., Meirold-Mautner, I., Defer, E., Prigent, C., Pardo, J. R., Mech, M., and Crewell, S.: A midlatitude precipitating cloud database validated with satellite observations, J. Appl. Meteorol. Clim., 47, 1337-1353, 2008.

Chaboureau, J.-P., Richard, E., Pinty, J.-P., Flamant, C., Di Girolamo, P., Kiemle, C., Behrendt, A., Chepfer, H., Chiriaco, M., and Wulfmeyer, V.: Long-range transport of Saharan dust and its radiative impact on precipitation forecast over western Europe: a case study during the Convective and Orographically induced Precipitation Study (COPS), Q. J. Roy. Meteor. Soc., 137, 236251, 2011.

Chaboureau, J.-P., Pantillon, F., Lambert, D., Richard, E., and Claud, C.: Tropical transition of a Mediterranean storm by jet crossing, Q. J. Roy. Meteor. Soc., 138, 596-611, 2012.

Chazette, P., Marnas, F., and Totems, J.: The mobile Water vapor Aerosol Raman LIdar and its implication in the framework of the HyMeX and ChArMEx programs: application to a dust transport process, Atmos. Meas. Tech., 7, 1629-1647, doi:10.5194/amt-71629-2014, 2014.

Clark, H. and Chaboureau, J.-P.: Uncertainties in short-term forecasts of a Mediterranean heavy precipitation event: assessment with satellite observations, J. Geophys. Res., 115, D22213, doi:2010JD014388, 2010.

Creamean, J. M., Suski, K. J., Rosenfeld, D., Cazorla, A., Demott, P. J., Sullivan, R. C., White, A. B., Ralph, F. M., 
Minnis, P., Comstock, J. M., Tomlinson, J. M., and Prather, K. A.: Dust and biological aerosols from the Sahara and Asia influence in the Western US, Science, 29, 1572-1578, doi:10.1126/science.1227279, 2013

Crumeyrolle, S., Gomes, L., Tulet, P., Matsuki, A., Schwarzenboeck, A., and Crahan, K.: Increase of the aerosol hygroscopicity by cloud processing in a mesoscale convective system: a case study from the AMMA campaign, Atmos. Chem. Phys., 8, 6907-6924, doi:10.5194/acp-8-6907-2008, 2008.

Cuxart, J., Bougeault, P., and Redelsperger, J. L.: A turbulence scheme allowing for mesoscale and large-eddy simulations. Q. J. Roy. Meteor. Soc., 126, 1-30, 2000.

Di Girolamo, P., Marchese, R., Whiteman, D. N., and Demoz, B. B.: Rotational Raman Lidar measurements of atmospheric temperature in the UV, Geophys. Res. Lett., 31, L01106, doi:10.1029/2003GL018342, 2004.

Di Girolamo, P., Summa, D., and Ferretti, R.: Multiparameter Raman Lidar measurements for the characterization of a dry stratospheric intrusion event, J. Atmos. Ocean. Tech., 26, 1742-1762, 2009.

Di Girolamo, P., Flamant, C., Cacciani, M., Richard, E., Ducrocq, V., Summa, D., Stelitano, D., Fourrié, N., and Said, F.: Observation of low-level wind reversals over the Gulf of Lion and their impact on the water vapor variability, Q. J. Roy. Meteor. Soc., in review, 2015.

Escudero, M., Castillo, S., Querol, X., Avila, A., Alarcon, M., Viana, M. M., Alastuey, A., Cuevas, E., and Rodriguez, S.: Wet and dry African dust episodes over Eastern Spain, J. Geophys. Res., 110, D18S08, doi:10.1029/2004JD004731, 2005.

Flamant, C., Chaboureau, J.-P., Parker, D. J., Taylor, C. M., Cammas, J.-P., Bock, O., Timouck, F., and Pelon, J.: Airborne observations of the impact of a convective system on the planetary boundary layer thermodynamics and aerosol distribution in the inter-tropical discontinuity region of the West African Monsoon, Q. J. Roy. Meteor. Soc., 133, 1175-1189, doi:10.1002/qj.97, 2007.

Flamant, C., Knippertz, P., Parker, D., Chaboureau, J.-P., Lavaysse, C., Agusti-Panareda, A., and Kergoat, L.: The impact of a mesoscale convective system cold-pool on the northward propagation of the inter-tropical discontinuity over West Africa, Q. J. Roy. Meteor. Soc., 135, 139-165, 2009a.

Flamant, C., Lavaysse, C., Todd, M., Chaboureau, J.-P., and Pelon, J.: Multi-platform observations of a springtime case of Bodélé and Sudan dust emission, transport and scavenging over West Africa, Q. J. Roy. Meteor. Soc., 135, 413-430, 2009b.

$\mathrm{Fu}$, R., Del Genio, A., and Rossow, W. B.: Behavior of deep convective clouds in the tropical Pacific from ISCCP radiances, J. Climate, 3, 1129-1152, 1990.

Grini, A., Tulet, P., and Gomes, L.: Dusty weather forecasts using the MesoNH mesoscale atmospheric model. J. Geophys. Res., 111, D19205, doi:10.1029/2005JD007007, 2006.

Huang, J., Lin, B., Minnis, P., Wang, T., Wang, X., Hu, Y., Yi, Y., and Ayers, K.: Satellite-based assessment of possible dust aerosols semi-direct effect on cloud water path over East Asia, Geophys. Res. Lett., 33, L19802, doi:10.1029/2006GL026561, 2006a.

Huang, J., Minnis, P., Lin, B., Wang, T., Yi, Y., Hu, Y., SunMack, S., and Ayers, K.: Possible influences of Asian dust aerosols on cloud properties and radiative forcing observed from MODIS and CERES, Geophys. Res. Lett., 33, L06824, doi:10.1029/2005GL024724, 2006b.

Huang, J., Fu, Q., Su, J., Tang, Q., Minnis, P., Hu, Y., Yi, Y., and Zhao, Q.: Taklimakan dust aerosol radiative heating derived from CALIPSO observations using the Fu-Liou radiation model with CERES constraints, Atmos. Chem. Phys., 9, 4011-4021, doi:10.5194/acp-9-4011-2009, 2009.

Huang, J., Wang, T., Wang, W., Li, Z., and Yan, H.: Climate effects of dust aerosols over East Asian arid and semiarid regions, J. Geophys. Res., 119, 11398-11416, doi:10.1002/2014JD021796, 2014.

Lafore, J. P., Stein, J., Asencio, N., Bougeault, P., Ducrocq, V., Duron, J., Fischer, C., Héreil, P., Mascart, P., Masson, V., Pinty, J. P., Redelsperger, J. L., Richard, E., and Vilà-Guerau de Arellano, J.: The Meso-NH Atmospheric Simulation System. Part I: adiabatic formulation and control simulations, Ann. Geophys., 16, 90-109, doi:10.1007/s00585-997-0090-6, 1998.

Lau, K. M., Kim, M. K., and Kim, K. M.: Asian monsoon anomalies induced by aerosol direct effects, Clim. Dynam., 26, 855-864, doi:10.1007/s00382-006-0114-z, 2006.

Lemaître, C., Flamant, C., Cuesta, J., Raut, J.-C., Chazette, P., Formenti, P., and Pelon, J.: Radiative heating rates profiles associated with a springtime case of Bodélé and Sudan dust transport over West Africa, Atmos. Chem. Phys., 10, 8131-8150, doi:10.5194/acp-10-8131-2010, 2010.

Masson, V., Le Moigne, P., Martin, E., Faroux, S., Alias, A., Alkama, R., Belamari, S., Barbu, A., Boone, A., Bouyssel, F., Brousseau, P., Brun, E., Calvet, J.-C., Carrer, D., Decharme, B., Delire, C., Donier, S., Essaouini, K., Gibelin, A.-L., Giordani, H., Habets, F., Jidane, M., Kerdraon, G., Kourzeneva, E., Lafaysse, M., Lafont, S., Lebeaupin Brossier, C., Lemonsu, A., Mahfouf, J.-F., Marguinaud, P., Mokhtari, M., Morin, S., Pigeon, G., Salgado, R., Seity, Y., Taillefer, F., Tanguy, G., Tulet, P., Vincendon, B., Vionnet, V., and Voldoire, A.: The SURFEXv7.2 land and ocean surface platform for coupled or offline simulation of earth surface variables and fluxes, Geosci. Model Dev., 6, 929-960, doi:10.5194/gmd-6-929-2013, 2013.

Miller, R. L., Tegen, I., and Perlwitz, J.: Surface radiative forcing by soil dust aerosols and the hydrologic cycle, J. Geophys. Res., 109, D04203, doi:10.1029/2003JD004085, 2004.

Min, Q.-L., Li, R., Lin, B., Joseph, E., Wang, S., Hu, Y., Morris, V., and Chang, F.: Evidence of mineral dust altering cloud microphysics and precipitation, Atmos. Chem. Phys., 9, 3223-3231, doi:10.5194/acp-9-3223-2009, 2009.

Mlawer, E. J., Taubman, S. J., Brown, P. D., Iacono, M. J., and Clough, S. A.: Radiative transfer for inhomogeneous atmospheres: RRTM, a validated correlated-k model for the longwave, J. Geophys. Res., 102D, 16663-16682, 1997.

Moulin, C., Lambert, C. E., Dayan, U., Masson, V., Ramonet, M., Bousquet, P., Legrand, M., Balkanski, Y. J., Guelle, W., Marticorena, B., Bergametti, G., and Dulac, F.: Satellite climatology of African dust transport in the Mediterranean atmosphere, J. Geophys. Res., 103, 13137-13144, 1998.

Papayannis, A., Amiridis, V., Mona, L., Tsaknakis, G., Balis, D., Bösenberg, J., Chaikovski, A., De Tomasi, F., Grigorov, I., Mattis, I., Mitev, V., Müller, D., Nickovic, S., Pérez, C., Pietruczuk, A., Pisani, G., Ravetta, F., Rizi, V., Sicard, M., Trickl, T., Wiegner, M., Gerding, M., Mamouri, R. E., D’Amico, G., and Pappalardo, G.: Systematic lidar ob- 
servations of Saharan dust over Europe in the frame of EARLINET (2000-2002), J. Geophys. Res., 113, D10204, doi:10.1029/2007JD009028, 2008.

Pergaud, J., Masson, V., Malardel, S., and Couvreux, F.: A parameterization of dry thermals and shallow cumuli for mesoscale numerical weather prediction, Bound.-Lay. Meteorol., 132, 83106, doi:10.1007/s10546-009-9388-0, 2009.

Pey, J., Querol, X., Alastuey, A., Forastiere, F., and Stafoggia, M.: African dust outbreaks over the Mediterranean Basin during 2001-2011: $\mathrm{PM}_{10}$ concentrations, phenomenology and trends, and its relation with synoptic and mesoscale meteorology, Atmos. Chem. Phys., 13, 1395-1410, doi:10.5194/acp-13-13952013, 2013.

Pinty, J.-P. and Jabouille, P.: A mixed-phase cloud parameterization for use in a mesoscale non-hydrostatic model: Simulations of a squall line and of orographic precipitations, Preprints, Conf. on Cloud Physics, 17-21 August 1998, Everett, WA, USA, Amer. Meteor. Soc., 217-220, 1998.

Querol, X., Pey, J., Pandolfi, M., Alastuey, A., Cusack, M., Moreno, T., Viana, M., Mihalopoulos, N., Kallos, G., and Kleanthous, S.: African dust contributions to mean ambient $\mathrm{PM}_{10}$ levels across the Mediterranean Basin, Atmos. Environ., 43, 42664427, 2009.

Rose, C., Sellegri, K., Freney, E., Dupuy, R., Colomb, A., Pichon, J.-M., Ribeiro, M., Bourianne, T., Burnet, F., and Schwarzenboeck, A.: Airborne measurements of new particle formation in the free troposphere above the Mediterranean Sea during the HYMEX campaign, Atmos. Chem. Phys., 15, 10203-10218, doi:10.5194/acp-15-10203-2015, 2015.

Rosenfeld, D., Rudich, Y., and Lahav, R.: Desert dust suppressing precipitation: A possible desertification feedback loop, P. Natl. Acad. Sci. USA, 98, 5975-5980, doi:10.1073/pnas.101122798, 2001.

Rysman, J.-F., Claud, C., Chaboureau, J.-P., Delanoë, J., and Funatsu, B. M.: Severe convection in the Mediterranean from microwave observations and a convection-permitting model, Q. J. Roy. Meteor. Soc., doi:10.1002/qj.2611, in press, 2015.

Saunders, R., Matricardi, M., Brunel, P., English, S., Bauer, P., O'Keeffe, U., Francis, P, and Rayer, P.: RTTOV-8 science and validation report, NWP SAF Report 41, available at: https://nwpsaf.eu/deliverables/rtm/rttov8_svr.pdf (last access: 3 November 2015), 2005.

Söhne, N., Chaboureau, J.-P., and Guichard, F.: Verification of cloud cover forecast with satellite observation over West Africa, Mon. Weather Rev., 136, 4421-4434, 2008.

Solmon, F., Mallet, M., Elguindi, N., Giorgi, F., Zakey, A., and Konaré, A.: Dust aerosol impact on regional precipitation over western Africa, mechanisms and sensitivity to absorption properties, Geophys. Res. Lett., 35, L24705, doi:10.1029/2008GL035900, 2008.
Stein, J., Richard, E., Lafore, J. P., Pinty, J. P., Asencio, N., and Cosma, S.: High-resolution non-hydrostatic simulations of flash-flood episodes with grid-nesting and icephase parameterization, Meteorol. Atmos. Phys., 72, 203-221, doi:10.1007/s007030050016, 2000.

Tao, W.-K., Chen, J.-P., Li, Z., Wang, C., and Zhang, C.: Impact of aerosols on convective clouds and precipitation, Rev. Geophys., 50, RG2001, doi:10.1029/2011RG000369, 2012.

Tulet, P., Crassier, V., Cousin, F., Shure, K., and Rosset, R.: ORILAM, A three moment lognormal aerosol scheme for mesoscale atmospheric model. On-line coupling into the MesoNH-C model and validation on the Escompte campaign, J. Geophys. Res., 110, D18201, doi:10.1029/2004JD005716, 2005.

Tulet, P., Mallet, M., Pont, V., Pelon, J., and Boone, A.: The 713 March 2006 dust storm over West Africa: generation, transport and vertical stratification, J. Geophys. Res., 113, D00C08, doi:10.1029/2008JD009871, 2008.

van den Heever, S. C., Carrio, G., Cotton, W. R., DeMott, P. J., and Prenni, A. J.: Impacts of nucleating aerosol on Florida convection: Part I. Mesoscale simulations, J. Atmos. Sci., 63, 17521775, doi:10.1175/JAS3713.1, 2006.

Vié, B., Pinty, J.-P., Berthet, S., and Leriche, M.: LIMA (v1.0): a two-moment microphysical scheme driven by a multimodal population of cloud condensation and ice freezing nuclei, Geosci. Model Dev. Discuss., 8, 7767-7820, doi:10.5194/gmdd-8-77672015, 2015.

Wulfmeyer, V., Behrendt, A., Bauer, H. S. , Kottmeier, C., Corsmeier, U., Blyth, A., Craig, G., Schumann, U., Hagen, M., Crewell, S., Di Girolamo, P., Flamant, C., Miller, M. Montani, A., Mobbs, S., Richard, E., Rotach, M., Arpagaus, M., Russchenberg, H., Schlüssel, P., König, M., Gärtner, V., Steinacker, R., Dorninger, M., Turner, D., Weckwerth, T., Hense, A., and Simmer, C.: The Convective and Orographicallyinduced Precipitation Study (COPS): A Research Project for Improving Quantitative Precipitation Forecasting in Low-mountain Regions, B. Am. Meteorol. Soc., 89, 1477-1486, 2008.

Zender, C. S., Bian, H. S., and Newman, D.: Mineral Dust Entrainment and Deposition (DEAD) model: Description and 1990s dust climatology, J. Geophys. Res., 108, 4416-4434, doi:10.1029/2002JD002775, 2003.

Zhao, C., Liu, X., and Leung, L. R.: Impact of the Desert dust on the summer monsoon system over Southwestern North America, Atmos. Chem. Phys., 12, 3717-3731, doi:10.5194/acp-12-37172012, 2012. 